\title{
Maternity Entitlements in India: Women's Rights Derailed
}

\author{
Jean Drèze \\ Reetika Khera \\ Anmol Somanchi *
}

April 7, 2021

\begin{abstract}
Maternity benefits of at least Rs. 6,000 per child are a legal right of all Indian women under the National Food Security Act, 2013. In practice, a large majority are still deprived of maternity benefits. A recent survey, conducted in six states of north India, brings out that pregnant women's basic needs for nutritious food, proper rest and health care are rarely satisfied. Among women who had delivered a child during the 6 months preceding the survey, about half said that they had been eating less rather than more during pregnancy, and nearly 40 per cent complained of a lack of rest at that time. The figures are much worse in states like Uttar Pradesh, where, for instance, one third of the same women had not had a single ante-natal checkup. Average weight gain during pregnancy was just $7 \mathrm{~kg}$ over nine months in this sample, down to $4 \mathrm{~kg}$ in Uttar Pradesh. Aside from poor nutrition, lack of rest appears to be a major factor of low weight gain during pregnancy. There is an urgent need for better recognition of the special needs of pregnancy, provision of maternity benefits in accordance with the law, and better support for pregnant women including quality health care.
\end{abstract}

${ }^{*}$ Affiliations: Department of Economics, Ranchi University (jaandaraz@riseup.net); Indian Institute of Technology, Delhi (reetika@riseup.net); independent researcher (anmol.smnch@protonmail.com). We are grateful to Kanika Sharma for helpful comments, to Chaupal in Ambikapur (Chhattisgarh) and Sanjana Patro for help with the training and debriefing workshops, and to Shyamasree Dasgupta, Sachin Jain, Rajkishor Mishra, Sangeeta Sahu, Sulakshana Nandi and Gangaram Paikra for their guidance in specific states. This study has also benefited from earlier work in collaboration with Aarushi Kalra and Aditi Priya. 


\section{Maternity Entitlements in India: Women's Rights Derailed}

Debates on maternity benefits in the Bombay Legislative Council in the 1920s make for interesting reading today. The topic was discussed not just once but several times between 1922 and 1928 (Chhachhi, 1998). After the Bombay Maternity Benefit Bill was introduced, in July 1928, there were spirited debates between representatives of interested parties mainly the government, the factory owners, and the working class. It is in this context that Dr. Ambedkar intervened to defend the bill and, with characteristic eloquence, refuted the arguments against it one by one. ${ }^{1}$ One misses this sort of debate in the Indian Parliament today - when debates take place at all.

The Bombay Maternity Benefit Act 1929 was the first of its kind in India. Later on, similar acts saw the light of day in other provinces, and then, in 1961, the central Maternity Benefit Act came into force across the country. So far so good.

\section{Some Women Are More Equal Than Others}

India's Maternity Benefit (Amendment) Act in 2017 was widely celebrated as it increased the maximum duration of paid maternity leave from 12 to 26 weeks. ${ }^{2}$ However, this provision effectively applies to a tiny fraction of women workers - mainly among those employed in the formal, organized sector (Uma and Kamath, 2019, see also Appendix). In fact, that law has been used to create a misleading perception, in some international forums, that India has some of the most generous maternity leave provisions in the world. Some women are more equal than others in this respect: relatively privileged women get maternity benefits based on the wage compensation principle (as they should), but the most disadvantaged are entitled to measly amounts (see Table 1). This stark asymmetry is barely noticed.

In 2013, maternity benefits became a legal entitlement of all Indian women (except those already receiving similar benefits as regular government employees or under other laws) under the National Food Security Act (NFSA), Section 4: “... every pregnant and lactating mother shall be entitled to [nutritious food and] maternity benefit of not less than rupees six thousand, in such instalments as may be prescribed by the Central Government".

At that time, a pilot scheme called Indira Gandhi Matritva Sahyog Yojana (IGMSY), with

\footnotetext{
${ }^{1}$ Government of Maharashtra (2005), p. 166. Dr. Ambedkar also discussed who should pay for maternity benefits. Despite acknowledging that "the burden of this ought to be largely borne by the Government", he supported the bill in its existing form, where the burden was borne by the employer - perhaps to expedite the passage of the bill.

2 This provision is now part of the Code on Social Security, 2020. The Code also consolidates a number of provisions for maternity benefits from earlier laws (now repealed) such as the Unorganised Workers' Social Security Act 2008 and the Building and Other Construction Workers' Welfare Cess Act 1996. These provisions, however, have remained largely symbolic so far.
} 
benefits of Rs. 4,000 per child, was being implemented in 53 districts. Under IGMSY, maternity benefits were conditional and restricted to two live births.

On 30 October 2015, in response to queries about the implementation of Section 4 of the NFSA, the Ministry of Women and Child Development (MoWCD) filed an affidavit in the Supreme Court claiming that it was planning to extend IGMSY from 53 to 200 districts in 2015-16 and all districts in 2016-17. Yet, the budget allocation for IGMSY in the 201617 Union Budget remained a mere Rs. 400 crore (as in 2015-16 and 2014-15), making it impossible to go beyond the 53 pilot districts. This was all the more puzzling as the importance of maternity entitlements had been well articulated in the Government of India's Economic Survey 2015-16, in a special chapter on "Mother and Child" (Government of India, 2016).

It is only in 2017 that the central government finally formulated a new maternity benefit scheme under Section 4 of NFSA, the Pradhan Mantri Matru Vandana Yojana (PMMVY). An allocation of Rs. 2,700 crores was made for this in the Union Budget 2017-18. However, this is a fraction of what is required: universal maternity entitlements of Rs. 6,000 per child would need at least Rs. 14,000 crore per year. ${ }^{3}$ Figure 1 compares this with actual financial allocations for maternity entitlements in the Union Budget in the last few years.

On 3 April 2017, the MoWCD stated the following in another affidavit to the Supreme Court: “... the Government of India has announced pan-India implementation of Maternity Benefit Programme with effect from 01.01.2017 in all the districts of the country. All the pregnant women and lactating mothers would be given Rs. 6,000 in instalments [except those already receiving similar benefits as regular government employees or under other laws]". However, when the PMMVY guidelines and draft Rules were released in August 2017, it emerged that maternity benefits were restricted to "the first living child" - a flagrant violation of the Act. ${ }^{4}$ Even for the first live birth, benefits have been arbitrarily reduced to Rs.5,000, instead of Rs. 6,000. Conditionalities also apply.

In 2017-18, the first year of PMMVY, effective coverage was virtually nil. From then on, coverage expanded gradually. Table 2 presents all-India coverage estimates for 2018-19 and 2019-20, excluding three states (Odisha, Tamil Nadu and Telangana) that have alternative maternity benefit schemes of their own. ${ }^{5}$ By 2019-20, the number of women who received at least one instalment of PMMVY outside these three states was around $78 \%$ of the estimated number of first births in that year. This may not look so bad, but partly because of a backlog

${ }^{3}$ This estimate assumes a population of 132 crore (2018 projection from National Commission on Population (2020)), a birth rate of 20 per thousand (2018 estimate from Sample Registration Bulletin, May 2019) and an effective coverage of 90 per cent.

${ }^{4}$ The precise meaning of "first living child" is not entirely clear from the guidelines. In practice, it seems to mean first live birth.

${ }^{5}$ See Table 1. These three state schemes preceded PMMVY. A few states have "supplementary" schemes that provide benefits additional to PMMVY - see Appendix for details. 
effect (i.e. payments made for births registered in the previous year). ${ }^{6}$ Further, coverage declines sharply as we look beyond the first instalment. The number of women who received the third instalment of PMMVY money in 2019-20 was only $48 \%$ of the estimated number of first births, and just $24 \%$ of all births (in a steady-state with universal coverage, the last figure would be close to 100\%). PMMVY coverage almost certainly declined in 2020-21, when the country was hit by the Covid-19 crisis. Indeed, according to the 2021-22 Budget documents, actual PMMVY expenditure in 2020-21 was just Rs. 1,300 crore as against a budget allocation of Rs. 2,500 crore. Expenditure data (Figure 1) clearly point to a large shortfall between PMMVY coverage and the NFSA norms.

\section{The Jaccha-Baccha Survey (JABS)}

The Jaccha-Baccha Survey (JABS) was conducted by student volunteers in six states of north India: Chhattisgarh, Himachal Pradesh, Jharkhand, Madhya Pradesh, Odisha and Uttar Pradesh. It took place in mid-2019, except that Jharkhand was added a little later, in October 2019 - see Table 3a. ${ }^{7}$ Some of the survey instruments built on the insights of an earlier study of similar inspiration in Jharkhand (Kalra and Priya, 2020).

The survey was done on a shoestring budget. It covered one district in each state. Since a random sample of size one makes little sense, we selected the districts purposely - mainly relatively deprived districts at a reasonable distance from Ambikapur (Chhattisgarh), our headquarters. ${ }^{8}$ In each district, two blocks were selected at random. In each sample block, our aim was to survey six villages: three villages selected at random among those with a population between 800 and 1200 (the "target villages"), and a "neighbouring" village in each case. ${ }^{9}$ In each village, we asked the anganwadi worker for her list of pregnant and nursing women (here "nursing women" refers to women who delivered a baby during the preceding 6

\footnotetext{
${ }^{6}$ In 2019-20, 66.5 lakh women were "enrolled" while 91.2 lakh received PMMVY money (still excluding Odisha, Tamil Nadu, and Telangana). The RTI response on which these figures are based (see Appendix) also states "... [counts] from PFMS [Public Fund Management System] may also be received for beneficiaries which were enrolled in previous financial years".

${ }^{7}$ We shall also refer from time to time (mainly in footnotes) to further insights from a follow-up investigation in Panchmahal district of Gujarat, at the end of October 2019. For those who are foxed by the survey's acronym, "jaccha-baccha" is a colloquial term for "mother and child".

8 The survey districts were: Sarguja (Chhattisgarh), Kullu (Himachal Pradesh), Gumla (Jharkhand), Umaria (Madhya Pradesh), Sundargarh (Odisha) and Sonebhadra (Uttar Pradesh). In Himachal Pradesh, we selected a district (Kullu) with relatively high "multi-dimensional poverty" in the mid-altitude region, which is more characteristic of Himachali culture and society than Lahaul and Spiti on the one hand, and the plains adjoining Punjab on the other.

9 The basic criteria for on-the-spot selection of a neighbouring village were: (1) it should be within or near the same gram panchayat, but preferably not close to the target village; (2) it should preferably be a Dalit or Adivasi hamlet; (3) it should have at least one anganwadi; (4) it should be roughly within the 800-1200 population range, like target villages.
} 
months) - these lists are supposed to be fairly comprehensive. Then we interviewed as many as possible of these women. Prior to this, investigators made a surprise visit to the anganwadi and interviewed the anganwadi worker.

That, at any rate, was the idea. Of course, there were hurdles. Some villages had two anganwadis - we selected one at random. Some (about one fifth) of the nursing women on the anganwadi worker's list turned out to have delivered a little earlier than 6 months before the survey - we retained them in the sample. Some women, especially among those who were pregnant, had gone to their maika (parents' village) at the time of the survey. In some villages, the team ran out of time. In Jharkhand, the survey period (overlapping with Dusshera holidays) turned out to be too short and anganwadi workers were on strike, so the survey work fell short of target.

Still, the teams managed to complete most of the survey plan in about 12 villages in each state: fewer (8) in Jharkhand, and more (19) in Himachal Pradesh where anganwadis tend to have a small catchment area. In all, 706 women were interviewed in the six states: 342 pregnant women and 364 nursing women (Table 3a). Given the small sample size at the level of individual states, we focus mainly on the sample as a whole. Individual stories are also used below to illustrate the hardships experienced by many pregnant and nursing women in rural India.

The characteristics of sample households reflect the focus of the sample on relatively deprived areas. Two thirds belonged to Scheduled Caste (SC) or Scheduled Tribe (ST) communities, they owned less than two acres of agricultural land on average, and nearly half did not even possess a fan (Table 3b). ${ }^{10}$ The respondents, all women, had relatively low levels of school education: barely half could read fluently and a quarter could not read at all. Most of them got married soon after they turned 18 , if not before. A majority were managing the household in addition to working outside the house, either on the family land or as casual workers. Many of the respondents were not only poor but also visibly frail, undernourished and short of power in the family and society.

\section{Hidden Hardships: Pregnancy and Childbirth in Rural India}

Rani Gope (Sundargarh district, Odisha) delivered her child at the public hospital in Bisra. She is weak and has low blood pressure - five months after her delivery, she still loses consciousness from time to time. During her pregnancy, she was advised by her family to eat less. The child did not cry after being born, so they took her to the government hospital in Rourkela. There they were referred to a private hospital. This was very expensive - the

${ }^{10}$ Surprisingly (or perhaps not), the proportion of sample households with a toilet was barely $60 \%$, just a few months before India was officially declared "open defecation free". 
child was kept in the intensive care unit (ICU) for five days. They had to mortgage their land for a loan of Rs. 50,000, and also borrow from relatives (another Rs. 50,000). After a few days, they had exhausted all their cash reserves and moved back to the Rourkela government hospital where they got affordable care. The child continues to be unwell, does not sleep comfortably, and has a swollen head. The parents have been consulting a private doctor (each session costs Rs. 700), but there is no clear diagnosis yet.

The hardships endured by rural women during pregnancy and childbirth tend to go unnoticed. Their husbands and in-laws are often unable or unwilling to give them adequate support as they experience fatigue, illness and pain. Public services, too, are grossly deficient. The JABS survey sheds light on these hidden hardships (for a preview, see Table 4).

\subsection{Special Needs Unattended}

Sangeeta (Sonebhadra, Uttar Pradesh) lives with her five children in a miserable hut on the edge of their small plot of land. Her husband works in Bhabani and other places, from time to time, as a casual labourer. Sangeeta's situation looks very difficult (she had eight children, of whom three died) but she does not seem to think that her last pregnancy was a big deal. She said that she rested for six days after delivery, but more out of fear of being ostracized (women in her community are not supposed to touch any utensils after delivery, a time when they are considered untouchable) than out of exhaustion. Despite evident deprivations, she does not report any special problem with her last pregnancy.

We were shocked to find how little attention was being paid, in the sample households, to the special needs of pregnancy - good food, extra rest and health care. Often, family members or even women themselves had little awareness of these special needs. For instance, $48 \%$ of pregnant women and 39\% of nursing women in Uttar Pradesh (UP) had no idea whether or not they had gained weight during pregnancy. Similarly, there was little awareness of the need for extra rest during and after pregnancy.

\section{Frugal Diets}

Among other neglected needs is the need for nutritious food. Only $22 \%$ of the nursing women reported that they had been eating more than usual during their pregnancy, and just $31 \%$ said that they had been eating more nutritious food than usual (Table 4). The most commonly reported reason for not eating more is that pregnant women often feel unwell or lose appetite. ${ }^{11}$ Lack of resources, of course, does not help: for one thing, it makes it more difficult to provide or prepare the sort of food that a woman who feels unwell might like to eat. The proportion of nursing women who reported eating nutritious food (e.g. eggs, fish,

\footnotetext{
${ }^{11}$ Some respondents (or elder women in the family) also worried that eating a lot during pregnancy might lead to delivery complications as the baby grows bigger.
} 
milk, fruit) "regularly" during pregnancy was less than half in the sample as a whole, and just $12 \%$ in UP. The general practice seems to be for women to continue eating more or less as usual during their pregnancy.

\section{Low weight gain}

Poor diets contribute to low weight gain during pregnancy. The average weight gain reported by nursing women over nine months of pregnancy was barely $7 \mathrm{~kg}$ in the sample as a whole (in UP, just $4 \mathrm{~kg}$ ). Even these figures are likely to be overestimates, as they exclude women who did not know their weight gain at all (26\% of all nursing women). Some women were so light to start with that they weighed less than $40 \mathrm{~kg}$ at the end of their pregnancy. Figure 2 conveys how little the weight gain is, compared with illustrative norms. ${ }^{12}$

These findings are consistent with recent evidence of a serious problem of low weight among pregnant women in India, reflecting both chronic undernourishment and low weight-gain during pregnancy. The weight of Indian women at the end of their pregnancy is extremely low by international standards, even compared with poorer countries in south Asia and sub-Saharan Africa (Coffey and Hathi, 2016a, Table 1). Low weight of pregnant women is associated with low birth-weight of babies, and the latter, in turn, with stunting and other impairments later in life (Coffey and Hathi, 2016a,b).

\section{Lack of Rest}

Rest is another unmet need of many pregnant women. Almost all the respondents had done household work regularly during their last pregnancy. A significant minority (21\%) of nursing women said that no-one (not even a grown-up child) was available to help them with household work in that period. Some respondents were clear that rest was a luxury they could ill-afford. As Jayamala Devi (Uttar Pradesh) put it: "Aaram kar ke kya karenge, ghar ka itna saara kaam hai, kapda dhona, khaana banana, kaun karega?" (how can I take rest, there is so much household work - washing clothes, cooking food - who will do that?). Similarly, Rekha Lakra (Chhattisgarh) had to manage all the household chores as her husband was engaged with other work. She was in the fields when she experienced labour pains. That, it seems, is far from unusual: almost two thirds (63\%) of the respondents said that they had been working right until the day of delivery.

\footnotetext{
12 There are, it seems, no official national norms for weight gain during pregnancy in India. The National Rural Health Mission handbook on safe motherhood says "average weight gain during pregnancy is 9-11 kg" (Government of India, nd, p. 5), and that can perhaps be read as a minimum norm. The slightly higher norms used to construct Figure 2 were developed by the Institute of Medicine (2009) for American women. Two recent reviews of available evidence, one covering international cohorts across multiple nationalities (Goldstein et al., 2017) and one focused on Indian and Asian women (Arora and Aeri, 2019), conclude that women who gained too little or too much weight compared to IoM guidelines were at higher risk of adverse outcomes.
} 


\section{Weakness and exhaustion}

Due to lack of food and rest, most of the respondents had felt tired or exhausted during pregnancy. Among nursing women, as many as $49 \%$ reported at least one major symptom of weakness during pregnancy, such as swelling of feet (41\%), impairment of daylight vision $(17 \%)$ or convulsions $(9 \%)$ - see Table 4 .

Some pregnant women had eye-opening stories of weakness and exhaustion. Consider Janbai Baiga, a tribal woman in Madhya Pradesh. She and her husband barely manage to feed their four children. In between household work and casual labour, Janbai gets very little time to rest. She suffers from dizziness, numbness in the ears and pain in the abdomen. Whatever little nutritious food they can afford she keeps mainly for the children. She doesn't think that it will be possible for her to go to a hospital for delivery - "who will look after the four children?"

Amirati, also a tribal woman in MP, is another telling example. The investigators' notes speak for themselves: "This was a sad interview. The respondent had tears throughout. She kept whispering so that no-one could hear. She said that she was working too hard and that no-one helped her. There were other adults in the house, but because she is the bahu [daughter-in-law] she was made to do all the work. When we met her, around noon, she had just returned from working on the farm and had not eaten anything that morning. The family did not look very poor yet there was little care for Amirati."

Janbai and Amirati's stories convey how pregnant women are in a kind of lose-lose situation as far as living arrangements are concerned. If they live in a nuclear family, no-one may be around to help when they are tired. In a joint family, there are more people around, but if they don't help, it just means more work, aside from possible neglect or harassment from the in-laws. The only real respite, for many pregnant women, is to spend some time at their maika, if they get a chance.

\subsection{Dismal Health Services}

Sarita is a Dalit woman from Sonebhadra (UP). When she reached the hospital for delivery, she found it closed. The doctors, it seems, had taken a day off. So she had to deliver her baby in the verandah with the help of three female members of her in-laws' family. When she applied for Janani Suraksha Yojana (JSY), the money was denied to her on the grounds that there was no evidence of the delivery having happened in that hospital, where staff were on a "self-declared holiday" at that time. ${ }^{13}$

\footnotetext{
${ }^{13}$ JSY is a central government scheme introduced in 2005 to incentivize institutional deliveries. Accredited Social Health Activists (ASHAs) are in charge of connecting pregnant women with health services, starting from registration of the pregnancy right up to the delivery. Both the pregnant woman and the ASHA worker receive
} 
Renu Raidas (Umaria, MP) went to the Umaria district hospital three days before delivery. The staff was rude. She was given sleeping pills when she was in pain. Even though she wanted a normal delivery, she was advised a C-section. On the third day, the nurses started pushing her stomach vigorously - one nurse on each side. She shouted at them and they moved away, but then denied her care. Her father had to bribe the nurses to get them to look after Renu. The child was born stiff and could not move its body. Renu's family spent Rs. 5,000 at the district hospital. From there, they went to a private hospital in Katni and stayed there for three days, spending another Rs. 35,000. In spite of this, Renu's child was not cured. She blames the nurses for the child's deformity. The family had to borrow Rs. 40,000 from a moneylender at an interest rate of $5 \%$ per month.

Alia Naz (Sundergarh, Odisha) delivered her child in the dead of the night at the Bisra public hospital. There was no doctor around. The nurses who looked after her delivered without anesthesia or hot water. They demanded Rs. 1,500. Two days after she was discharged, the child stopped drinking milk, and on being taken to the hospital, she was diagnosed with some infection. She was admitted to the ICU in Rourkela government hospital. The family rented a room in a lodge nearby. A week later, the child was discharged. The doctor was of the opinion that this infection was due to unhygienic conditions at the time of delivery.

These three stories highlight a range of issues with maternal health facilities. Pregnant and nursing women are acutely deprived of quality health care. Many of them receive some elementary services such as tetanus injections and iron tablets at the local anganwadi or health centre (Tables 4 and 5), but they get very little beyond the basics. Small ailments easily become a major burden, in terms of pain or expenses or both. At the time of delivery, women are often sent to private hospitals when there are complications. A significant minority also report rude, hostile or even brutal treatment in the labour room, corroborating recent studies of "labour-room violence" in India. ${ }^{14}$

Two signs of recent improvement in maternal care services are high rates of institutional delivery and widespread use of public ambulance services (Table 5). Institutional deliveries, actively promoted from 2005 onwards under JSY, have become the norm in most of the JABS states; one notable exception is Uttar Pradesh, where 35\% of recent deliveries had taken place at home. The use of ambulance services, a more recent development, is also growing rapidly - a majority of nursing women had used them at the time of delivery, just by dialling "108". Some had to pay small charges - Rs. 58 on average. ${ }^{15}$ These are useful initiatives, and they also show the possibility of change, but there is an urgent need for more comprehensive

a cash incentive for each institutional delivery.

${ }^{14}$ See e.g. Goli et al. (2019), Sharma et al. (2019), Pant et al. (2021).

${ }^{15}$ A five-state study in Andhra Pradesh, Assam, Gujarat, Karnataka and Meghalaya conducted in 2014 found that ambulance services were predominantly used by rural or tribal women (92\%) and poorer women $(70 \%)$ (Strehlow et al., 2016). In their study in AP and HP, Singh et al. (2018) find that while ambulances reach most callers, they are not always assigned on request. The authors note the need for improving these services as the incidence of obstetric emergencies was higher among those who did not get (or request) an ambulance. 
and radical improvements in maternal care services.

\subsection{Delivery as an Economic Contingency}

Many of the women mentioned earlier, or their families, spent a lot of money on deliveryrelated expenses. For instance, Rani Gope's family had to rustle up Rs. 100,000, half of it by mortgaging their land. And Renu Raidas' family, now saddled with interest payments of Rs. 2,000 per month, risks economic ruin as the principal of Rs. 40,000 will grow at a compound rate of $5 \%$ per month if they fail to pay regular instalments.

Institutional deliveries are supposed to be available free of cost to all women in public health centres. In practice, deliveries are expensive, especially when women are referred to private hospitals, or taken there in the first place. On average, nursing women had spent about Rs. 6,400 on their last delivery (Table 5). This amounts to more than a month's wages for a casual labourer, in the survey areas. When there are complications, the cost often shoots up, as happened to Rani and Renu. A small minority (7\%) of nursing women who delivered at private institutions spent over Rs. 45,000 on average. One third of the nursing women's households had to borrow or sell assets to pay for delivery costs. The economic risks associated with pregnancy and delivery add to other arguments for universal maternity entitlements.

\subsection{Food, Rest and Weight Gain}

The survey findings point to a serious problem of unmet needs (for nutritious food, proper rest and health care in particular) during and after pregnancy. They also suggest that much can be done by public institutions, the family, and the woman herself to ensure that these needs are met. This calls for paying attention not only to the medical aspects but also to the social determinants of women's predicament during and after pregnancy.

The point can be pursued a little with reference to weight gain during pregnancy. Earlier literature highlights the role of good nutrition for adequate gestational weight gain, in turn associated with better outcomes for the new-born child. The JABS survey data suggest that, in addition to good nutrition, weight gain also depends on adequate rest.

Table 6 presents OLS regressions of average monthly weight gain during pregnancy on a range of individual and household characteristics. A fairly strong association emerges with indicators of good nutrition and especially rest, even after controlling for other variables and exploring alternative specifications. ${ }^{16}$ Aside from that, weight gain is positively associated

\footnotetext{
${ }^{16}$ Alternate specifications include using the log of monthly weight gain or cumulative weight gain, as the
} 
with education and economic status, as one might expect, and negatively associated with casual labour as a primary occupation. These are just statistical associations, but they are consistent with the notion that weight gain is strongly influenced by factors that are within reach of public action. Further investigation of these issues based on larger datasets would be most useful.

A related insight from the JABS survey is that women who spend some time at their parents' home around the end of their pregnancy (a common but far from universal practice in north India) seem to have a better chance of getting enough rest. As mentioned earlier, in nuclear families there are few helping hands for a pregnant woman, whereas in joint families, some help is more likely but the overall workload is also higher (more mouths to feed, more water and fuel to fetch, and so on). It is only at the maika that there is an assurance of someone else being in charge of the household work. Perhaps pregnant women also get more general care and attention there, and some relief from the stress of running a household.

\section{Leaders and Laggards}

The sample size of the JABS survey is too small to make detailed inter-state comparisons, but some contrasts familiar from earlier surveys did emerge once again.

Various studies have noted distinct regional variations in the scope and effectiveness of social policy initiatives in India (Drèze and Sen, 2013; Singh, 2015; Tillin et al., 2016; Drèze and Khera, 2017). Some states, like Kerala and Tamil Nadu, do consistently better than most other states in many areas of social policy, from health and education to nutrition and social security. Others, like Bihar and Uttar Pradesh, tend to have dismal public services across the board. In between, there are many states where public services still leave plenty to be desired, but with significant achievements in specific fields and a general trend of sustained improvement. Sometimes we have referred to these different groups of states as "leaders, laggards and learners" respectively, but the grouping is not static and also depends on the policy areas of interest.

As expected from earlier work, Himachal Pradesh stood out among the six JABS states for its relatively good public services including maternal care. Women in Himachal were also relatively well-off, well-educated and self-confident. Their predicament was much better than elsewhere, with, for instance, an average weight gain in pregnancy of more than $11 \mathrm{~kg}$ (see Table 7). Some respondents shared stories that were rarely heard in other states. Omlata, for instance, said that she ate and took rest whenever she felt like it, and that she had fruit, milk and curd every day. Others mentioned how their husband or in-laws reminded them

dependent variable, instead of average monthly weight gain, and adding more individual and household controls (such as birth order or social identity). 
of their need to rest and chipped in with household work, or how there had been informed discussions of matters related to pregnancy and maternal care within the family. Radha, a young Dalit, explained how she had been able to seek timely medical attention on her own initiative, when she suspected that her pregnancy was not going well.

In earlier surveys, we had also noted how Odisha, a low-income state often clubbed with the so-called BIMARU states (undivided Bihar, Madhya Pradesh, Rajasthan and Uttar Pradesh) not so long ago, was making steady progress in matters of food security, child nutrition and public health. This time, once again, we saw important signs of hope in Odisha. For instance, Odisha has its own maternity benefit scheme, the Mamata scheme. This scheme covers two births, not one, and seems to work relatively well: among the nursing women we interviewed, $88 \%$ of those who were eligible for Mamata had applied, and $75 \%$ of those who had applied had received at least one instalment. Women's awareness, understanding and utilization of the scheme was much higher for Mamata in Odisha than for PMMVY in other states (see also Table 9 below).

Another valuable initiative in Odisha is the regular provision of eggs in anganwadis. Not only do children aged 3-6 years get an egg five times a week with their midday meal, eggs are also distributed as "take-home ration" (THR) for younger children as well as pregnant and nursing women. This policy, also in place in a few other states, is begging to be adopted more widely. In some states, including Odisha, eggs are also on the menu in primary and upper-primary schools.

Judging from the JABS survey, the reach of ICDS services is also relatively good in Odisha, with near-universal coverage of basic services (health check-up, tetanus injections, iron and folic acid tablets, food supplements, etc.) among pregnant and nursing women registered at the anganwadi. The wide reach of ICDS services in Odisha is also reflected in the findings of the fourth National Family Health Survey (NFHS-4), conducted in 2015-16: in rural areas, $91 \%$ of pregnant women reported receiving some services from the local anganwadi. This includes supplementary nutrition $(90 \%)$, health check-ups $(86 \%)$, and health and nutrition education (82\%). ${ }^{17}$ In successive surveys, we also observed clear signs of active team work involving the local anganwadi worker (AWW), auxiliary nurse-midwife (ANM) and accredited social health activist (ASHA) - see e.g. Khera (2015).

Further, Odisha is the only sample state where a majority of the respondent households were covered under some form of health insurance - either a national scheme (Rashtriya Swasthya Bima Yojana or its successor, Ayushman Bharat), or the state's own health insurance scheme (Biju Swasthya Kalyan Yojana, launched in 2018). On this, again, our findings are consistent with NFHS-4 data: $52 \%$ of rural households in Odisha had at least one member covered by a health insurance scheme in 2015-16. Among these households, $42 \%$ were covered by the

\footnotetext{
${ }^{17}$ International Institute for Population Sciences (2017b, Table 59). Similar figures apply to breastfeeding women as well.
} 
state scheme, and $64 \%$ by RSBY. ${ }^{18}$

Odisha has every reason to aim at the same high standards of health and nutrition services as Himachal Pradesh relatively soon. Indeed, in some respects (e.g. coverage of maternity entitlements and health insurance), it is already ahead. Odisha being a very poor state, the predicament of pregnant and nursing women there was not as good as in Himachal Pradesh, but it was better than in the other sample states.

In Chhattisgarh too, we found many signs of hope such as brightly painted anganwadis, breakfast for the kids, a pre-school education syllabus, collaboration between anganwadi and health workers, etc. Some of these initiatives are yet to make a difference, but there is a trend of improvement at least. The state has made sustained efforts to improve anganwadis and primary health care. This shows, for instance, in joint health check-up and immunization sessions involving the local Mitanin (ASHA), AWW and ANM. Further, Chhattisgarh is one of the few states that have started providing a cooked meal to pregnant and nursing women at the local anganwadi. ${ }^{19}$ This, incidentally, is a legal right under Section 4 of the NFSA.

The laggard states in this survey were Jharkhand, Madhya Pradesh and especially Uttar Pradesh. In Madhya Pradesh, the picture was not all bleak - the "model" (aadarsh) anganwadis were relatively good, and hopefully similar standards can be achieved everywhere in the state. Almost every nursing woman there had delivered in a public institution and used a public ambulance. The general predicament of pregnant and nursing women, however, was not much better in Madhya Pradesh than in Jharkhand or Uttar Pradesh.

UP is the usual straggler, with abysmal socio-economic conditions, dismal services and abominable corruption. The lives of pregnant women in Himachal Pradesh and UP are poles apart, as Table 7 illustrates. In UP, their predicament is really grim. Only $15 \%$ of nursing women there had been eating more nutritious food than usual during their last pregnancy, just $64 \%$ had at least one health check-up, and a majority reported lack of adequate rest. All the anganwadis in our UP sample were closed at the time of the survey - ostensibly because of the school holidays. Women and children disliked the panjiri (ready-to-eat mixture) being distributed as THR, if they ate it at all. No food was ever cooked at anganwadis, even for children in the age group of 3-6 years. Pregnant women, largely left to their own devices, were struggling with the worst possible hardships and pains.

The qualitative survey notes from Uttar Pradesh are sad to read. Aches, weakness and lethargy were recurring themes in conversations with respondents. Teenage pregnancies, sometimes ending in a still birth or infant death, were not uncommon. Many women were struggling to meet their most basic needs, sometimes working for wages late into their

\footnotetext{
18 International Institute for Population Sciences (2017b, Table 80).

${ }^{19}$ Another early bird in this regard is Gujarat, as we learnt from the follow-up investigation in Panchamahal district. There, however, cooked meals for pregnant and nursing women were provided on a weekly rather than daily basis.
} 
pregnancy or soon after delivery.

Dev Kumari, for instance, had to work for wages to make ends meet during her pregnancy (her husband was working elsewhere). When she could not find work, she often ran out of money for food. She also fell sick several times during her pregnancy, incurring further expenses. She was only 15 when she had her first pregnancy, ending in a still birth. Similarly, Leelavati had a still birth at the age of 16 . She was near the end of her fifth pregnancy at the time of the survey, but only one child had survived. She said that she wanted to deliver as soon as possible so that she could get back to work.

Leelavati was among the few respondents in UP who said that her husband helped her with the housework. More often, the teams heard something like Anita Devi's statement: "Nobody was willing to fetch even a single bucket of water, I had to do it all by myself." The general disempowerment of women within the family was very stark in UP. Conversations with the respondents were often interrupted by or overseen by overbearing in-laws. Some of them even taunted the respondent in front of the survey team.

The findings of the JABS survey, including regional contrasts, are broadly consistent with NFHS- 4 data. Table 8 presents a sample of relevant NFHS-based indicators. ${ }^{20}$ Here again, there is evidence of a serious problem in Uttar Pradesh, where, for instance, only $60 \%$ of women had been weighed during their last pregnancy (lowest figure among major Indian states) and $4 \%$ had received all recommended types of antenatal care (second-lowest, after Bihar). Himachal Pradesh, by contrast, fares much better than the national average across the board.

\section{What is Wrong with PMMVY?}

Eight years after the National Food Security Act became law, the central government is yet to redeem one of its main responsibilities under the Act: payment of maternity benefits of Rs. 6,000 to all pregnant women. Even the meagre benefits under PMMVY (Rs. 5,000 for just one child), it turns out, are elusive: as mentioned earlier, PMMVY coverage was still quite patchy in 2019-20.

The lame coverage of PMMVY is also reflected in our sample (see Table 9). Among nursing women eligible for PMMVY, only $28 \%$ had received the first instalment. The coverage of the Mamata scheme in Odisha is much better in every respect - awareness levels, application rates, and actual benefits. Note also that outside Odisha, very few women get anything before

\footnotetext{
${ }^{20}$ The "JABS states" column in Table 8 should be read bearing in mind that these are population-weighted averages of state-specific figures. Some of them (e.g. institutional deliveries) look a little worse than the corresponding JABS-based figures because of the large share of Uttar Pradesh (over 50\%) in the aggregate population of the JABS states.
} 
the end of their pregnancy.

The JABS survey sheds some light on the reasons why many women are excluded from PMMVY. Briefly, women's rights under the NFSA have been denied in three ways.

\subsection{Restriction of entitlements}

As we saw, maternity benefits under PMMVY have been restricted to Rs. 5,000 for the first living child, in flagrant violation of the NFSA. Maternity entitlements have also been restricted in other ways. Consider Rita Devi (Kullu, HP), a childless woman who was pregnant when we met her but could not get PMMVY benefits because she had aborted her previous pregnancy. According to the anganwadi worker, the aborted child counts as the first child, because it was aborted in the fourth month, after the pregnancy had been registered. The AWW consulted the CDPO (block coordinator for ICDS), who said nothing could be done. Similarly, some women are deprived of PMMVY benefits because the child was born at home, for reasons that are not necessarily under their control. We also heard of cases where a second wife was denied PMMVY benefits, even for her first child, on the grounds that the first wife had already benefited from the scheme.

The main restriction, of course, is that there are no benefits beyond the first live birth under PMMVY. This is an odd restriction, since India does not have a one-child policy. ${ }^{21}$ It is also discriminatory: there is no such restriction for women in the organized sector. This restriction has seriously undermined PMMVY, by reducing the number of women who have a stake in it. If maternity benefits were universal, as prescribed under NFSA, it would be much easier for pregnant women to understand and claim their entitlements. Even extending maternity benefits to two children instead of one would make a major difference, as Odisha's Mamata scheme illustrates. ${ }^{22}$

\subsection{Cumbersome application process}

To receive these meagre benefits, eligible women need to fill a long form for each of the three instalments (the combined length was 23 pages at the time of the survey!). They also have to

\footnotetext{
${ }^{21}$ In any case, it is far from clear that extending PMMVY benefits beyond the first child would lead to higher fertility. Some recent evidence suggests the opposite (Haaren and Klonner, 2020, 2021).

22 During the follow-up investigation in Panchmahal district, we learnt that Gujarat also had a state scheme for maternity benefits, called Kasturba Poshan Sahay Yojana, as a supplement to PMMVY. This scheme, launched in 2017, extends beyond the first child, but only for BPL families. This restriction, like the restriction of PMMVY to the first living child, had severely reduced the appeal and vitality of the scheme. Many women were not even aware of it, and implementation was so patchy that it took two days for the survey team to ascertain that Kasturba Yojana was operational.
} 
produce their "mother-child protection" (MCP) card, Aadhaar card, husband's Aadhaar card, and bank passbook, aside from linking their bank account with Aadhaar. ${ }^{23}$ Further, they depend on the goodwill of the anganwadi worker and CDPO to ensure that the application is filed on-line. This entire process is challenging, especially for women with little education. ${ }^{24}$ Among the nursing women in our sample, $41 \%$ reported at least one major problem with the application process (Table 10a). Many were not even aware of PMMVY benefits at the time of the survey (Table 9).

\subsection{Unreliable payments}

Online PMMVY applications and payments are often rejected, delayed, or returned with error messages for a variety of reasons, some of which are familiar from studies of Aadhaarenabled payments of welfare benefits in other contexts (e.g. pensions and the National Rural Employment Guarantee Act). ${ }^{25}$ Examples include: (1) incomplete information, (2) inconsistencies between Aadhaar card and bank passbook; (3) diversion of payment to a wrong person's account. In cases of unsuccessful application or payment failure, there is no provision for informing the concerned women and explaining to them what needs to be done.

\section{Aadhaar Spanner in PMMVY Wheel}

The PMMVY application process is complicated to start with. The imposition of Aadhaar has created further complications. One-fifth of the respondents who had applied for PMMVY reported experiencing Aadhaar-related problems. In addition to this, there are Aadhaarrelated problems at the payment stage (e.g. when payments are made using the Aadhaar Payment Bridge System) that were mostly beyond the respondents' understanding, so that they did not attribute them to Aadhaar. Some of them were reported by anganwadi workers, who take care of application formalities on behalf of the women. Almost half of the AWWs had experienced similar problems themselves (Table 10b).

Remember, these young women are expecting a baby or nursing an infant and many of them need rest. Instead, they are constrained to spend time and money on fixing errors that have

\footnotetext{
${ }^{23}$ In principle, PMMVY payments can be made without the recipient's bank account being linked with Aadhaar. In practice, applicants are often told that Aadhaar linking is necessary. This seems to be part of the effort to promote the Aadhaar Payment Bridge System (APBS) for "direct benefit transfers" (DBT).

${ }^{24}$ On this see also Falcao et al. (2019a), Chandra (2020a), Kalra and Priya (2020). Application hurdles are also evident from official reports (e.g. Government of India (2018)).

${ }^{25}$ See e.g. Drèze (2018) and Dhorajiwala et al. (2019). On PMMVY-specific payment issues, see also Falcao et al. (2019b), Chandra (2020a,b), Kalra and Priya (2020), Paikra (2020). Some of them, like rejected payments, are visible in the government's own data (Khera and Somanchi, 2020).
} 
crept in for no fault of their own - with no guarantee that the issues will be resolved. Here is a brief recap of the Aadhaar-related issues we encountered during the survey.

One, Aadhaar is the only acceptable ID document for PMMVY. In principle, there is a provision for applying without Aadhaar, but in practice, Aadhaar is treated as mandatory. This creates serious problems for women who do not have Aadhaar, or lost their Aadhaar card, or find errors in their Aadhaar records. When Sushman Devi (Sonebhadra, UP) was trying to make corrections in her Aadhaar records, local officials kept delaying the matter. Ultimately, she had to borrow Rs. 2,000 from her sister to get corrections made to her and her husband's Aadhaar cards at the block headquarters.

Two, PMMVY benefits (in contrast with Odisha's Mamata scheme) also require verification of the husband's identity, again based on his Aadhaar card. There were cases where women had not been able to apply, or the application had been delayed, because of failure to produce the husband's Aadhaar card. Some husbands did not have Aadhaar cards, some women were living with men to whom they were not married, or were single mothers.

There were many cases where an application had been delayed or stalled because the applicant's Aadhaar card still carried her parents' address instead of her in-laws' address. ${ }^{26}$ For instance Pooja, who is from Uttar Pradesh but married to someone in Sarguja (Chhattisgarh), had no way of providing a proof of her new address. The Aadhaar enrolment centre advised her to get a certificate from the sarpanch, but later rejected the certificate. Many women such as Krishna Baiga and Sunita in Umaria (Madhya Pradesh) tried but failed to get their Aadhaar address updated. When Dinesh Mehta (HP) went to get her address updated, the machine did not work. The Mamata scheme in Odisha, once again, seems more user-friendly in this regard: some women there reported being able to get their maternity benefits without updating their Aadhaar address.

Three, there are frequent inconsistencies of demographic information between a woman's Aadhaar card and other documents such as her application form or bank passbook. Minor discrepancies or glitches (e.g. typos in Aadhaar number, misspelling of names, wrong date of birth on Aadhaar card, mismatch between Aadhaar card and other records, etc.) can all lead to a PMMVY application being rejected or delayed. In Odisha, Rani Gope had to get multiple corrections made to the date of birth on her Aadhaar card. Hulari Munda (also in Odisha) has three IDs, each of which shows a different date of birth. Marcilin Munda's Aadhaar card overstates her age by 10 years. These are just some examples of the data glitches that may arise. $^{27}$

\footnotetext{
${ }^{26}$ Some women also said that local officials insisted on their husband's (not their father's) name being mentioned on their Aadhaar card. Chandra (2020a) reports a similar problem in Gujarat.

27 On this, see also Vipul Paikra's insightful account of Aadhaar-related problems in PMMVY applications in Chhattisgarh (Paikra, 2020). According to one data-entry operator quoted there, "a spelling mistake or a dot after the name or even an extra space can take the application to the correction queue".
} 
In most cases, these errors creep in for no fault of the women concerned, but they are paying the price for it. Further, the steps required to make these corrections are not clearly defined or communicated. We also met women who came back with new errors when they went to correct an earlier mistake in their Aadhaar records. In what will likely make matters worse, a recent central-government circular (dated 14 October 2019) restricts the number of changes of demographic information in the Aadhaar card to once in a lifetime for gender and date of birth, and twice in a lifetime for name.

Four, problems often arise from the insistence on bank accounts being linked with Aadhaar. Women such as Sukiya Baiga (Madhya Pradesh) could not open a bank account because she did not have Aadhaar; others faced difficulties because their bank account was not linked to Aadhaar, despite repeated attempts in some cases. Sadhna (Madhya Pradesh) has an account and an Aadhaar card, but linking is creating difficulties. Others, such as Santoshi (HP), find that their Aadhaar is linked to an account different from the account they mentioned in their PMMVY application. Resolving these issues is cumbersome and time-consuming.

Five, there were other complications, including cases where even the anganwadi worker and/or bank official were unable to figure out what the problem was. Laxmi (HP) was told that there is an "Aadhaar card problem" with her PMMVY application, without elaboration. Some women were asked for a bribe by the AWW of ASHA when their assistance was required to solve Aadhaar-related issues. For instance, the ASHA worker in Parvati's natal village in UP told her that she could get the PMMVY form filled without the presence of her husband for a charge of Rs. 500 .

NITI Aayog itself reported alarming evidence of the unreliable nature of PMMVY payments around the time of the JABS survey:

A substantial number of payments (28\% cases of all Aadhaar based payments, i.e. in case of 31.29 lakh payments) are going to different Bank Accounts than what had been provided by the Beneficiaries. Sometimes these are even untraceable by beneficiaries and field functionaries. A telephonic survey of 5,525 beneficiaries was conducted by MoWCD which has revealed that only $60 \%$ were aware of both the receipt of the benefits and the bank account to which the money was remitted. ${ }^{28}$

A follow-up report released in 2020 suggests that these problems persisted and perhaps even worsened in the intervening period (NITI Aayog, 2020, p. 49). PMMVY is nowhere out of the woods.

\footnotetext{
${ }^{28}$ NITI Aayog (2019), p. 22. Similar findings are reported in Ghatak and Muralidharan (2020), with specific reference to Jharkhand.
} 


\section{$7 \quad$ ICDS and Maternity Entitlements}

The ICDS programme, mentioned off and on so far, plays a key role in the realization of maternity entitlements. The anganwadi is the bridge that connects children under six as well as pregnant and nursing women with government services. Hot cooked meals are provided to children aged 3-6 years and are also supposed to be provided (under the NFSA) to pregnant and nursing women. For children aged 6 months to three years, and for pregnant and nursing women, there is a provision of "take-home rations". Anganwadis also deliver health services such as immunization, iron supplementation and growth monitoring aside from pre-school education.

The anganwadi worker plays an important role in PMMVY because she is supposed to help pregnant women to apply for benefits and forward their applications to the block. She plays a similar role for related purposes such as JSY benefits, often in liaison with the health department (e.g. through the ASHA worker for institutional deliveries). The ICDS infrastructure is now widely utilized for multiple schemes. The AWW, ASHA and ANM can make a good team and complement each other's work.

A slow but steady expansion in the reach and range of ICDS services is evident from successive National Family Health Surveys. Tables $11 \mathrm{a}$ and $11 \mathrm{~b}$ present some relevant indicators from NFHS-4 for the JABS states. Except in Uttar Pradesh, a large majority of children under six and pregnant or nursing women receive some ICDS services, including food supplements in most cases. In states like Chhattisgarh and Odisha, where ICDS is relatively well integrated with health services, health check-ups at the anganwadi have also become the norm for the same groups. ${ }^{29}$

During the JABS survey, we also noticed some important signs of improvement in ICDS services. For instance, the nutritional value of cooked meals and take-home rations has recently been enhanced in several states. The provision of eggs in Odisha was especially encouraging. Similarly, pre-school education, much neglected for a long time, is being taken more seriously today. Barring UP, for instance, almost all AWWs reported having a "syllabus" for this purpose; some states also provide uniforms for the children.

In all the sample states, however, child attendance at anganwadis on the day of the survey was low: just a few children in most cases. Perhaps this was, at least partly, a seasonal effect, related for instance to the numbing heat (most anganwadis in the sample villages had no fan) and school holidays (when elder siblings are at home, younger children may be more likely to skip the anganwadi). Still, the attendance gap was clearly more than a transient problem. Sending young children to the anganwadi needs to become the norm, just like sending older children to school has become the norm. Fostering this norm requires special

\footnotetext{
${ }^{29}$ In Himachal Pradesh, immunization and health check-ups normally happen at local health centres rather than at anganwadis. Health centres there are doing relatively well (Goel and Khera, 2015).
} 
measures such as attractive premises, nutritious food menus and awareness drives through community institutions (e.g. gram panchayats, gram sabhas and self-help groups). In some areas, anganwadis also need to be more accessible, especially to marginalised communities. ${ }^{30}$

\section{Concluding Remarks}

The provision for universal maternity entitlements in India's National Food Security Act 2013 is a historic move but its significance, it seems, was lost on the Indian government as well as on the public. Recent inventories of social protection policies by the International Policy Center for Inclusive Growth in collaboration with UNDP and UNICEF suggest that only two other countries in Asia and Africa have universal, non-contributory maternity benefits: Mongolia (where fertility is encouraged due to very low population density) and Nepal (with very low benefits per child). ${ }^{31}$ The reason for this gap cannot be that maternity entitlements are very expensive: as of now, India spends less than $0.01 \%$ of its GDP on PMMVY, and even our estimate of the cost of actual universalization at NFSA rates (Rs. 14,000 crore) is less than $0.05 \%$ of India's GDP.

The JABS survey brings out that pregnant women's basic needs for nutritious food, proper rest and health care are rarely satisfied in rural India. Timely payment of maternity benefits on a universal basis would help them to face the multiple contingencies (also including delivery costs) they are exposed to. Cash support, of course, needs to be supplemented with other measures such as nutrition and health services as well as efforts to question the patriarchal norms that put pregnant women in such a difficult situation.

Two years after the JABS survey, a number of developments make it all the more urgent to pay greater attention to maternal care and maternity entitlements. First, partial findings of the fifth National Family Health Survey, carried out in 2019-20 (just before the Covid-19 crisis), point to an alarming stagnation of child nutrition in the preceding four years (Drèze, 2020). Second, the Covid-19 crisis and the economic recession it precipitated in 2020 almost certainly led to a significant worsening of the nutrition situation. Third, in spite of this nutrition crisis, financial allocations for ICDS, maternity benefits, and the Ministry of Women and Child Development as a whole were slashed in the 2021-22 Union Budget. ${ }^{32}$ This came

\footnotetext{
${ }^{30}$ Much else, of course, needs to be done to improve ICDS services. For some useful proposals, see Centre for Equity Studies (2016), Citizens' Initiative for the Rights of Children Under Six (2006), Dasgupta (2021), John et al. (2020), among others.

31 See IPC-IG and UNDP (2016) and IPC-IG and UNICEF (2019).

32 The Ministry's budget was reduced by nearly $20 \%$ (from Rs. 30,007 crore in 2020-21 to Rs. 24,435 crore in 2021-22). In the 2021-22 Union Budget, anganwadi services have been clubbed with three other programmes under the new SAKSHAM scheme; yet, the SAKSHAM budget in 2021-22 (Rs 20,105 crore) is less than the budget for anganwadi services alone in 2020-21 (Rs. 20,532). Similarly, PMMVY has now been clubbed with other schemes under SAMARTHYA. Yet, the SAMARTHYA allocation in 2021-22 (Rs. 2,522 crore) is similar to the allocation for PMMVY alone in 2020-21 (Rs. 2,500 crore).
} 
on top of an earlier round of cuts, in 2015-16. In real terms, the allocation for ICDS in the Union Budget is about $40 \%$ lower today than it was seven years ago.

There was a severe setback in the payment of maternity benefits during the Covid-19 crisis. Expenditure on PMMVY was just Rs. 1,300 in 2020-21, as against a budget allocation of Rs. 2,500 in 2020-21 and actual expenditure of around Rs. 2,300 in 2019-20. ${ }^{33}$ This crash probably reflects the disruption of routine health and nutrition services in 2020 (Drèze and Paikra, 2020), including the closure of anganwadis for an extended period.

Against this background, it is essential to revive the agenda of universal maternity entitlements. Notwithstanding the low and outdated norm of Rs. 6,000 per child, this was the most innovative provision of the NFSA, but it has been badly derailed. The government keeps evading this issue, the parliament never discussed it, the media are paying no attention, and even the Supreme Court does not seem to consider it important to protect women's rights under the Act. ${ }^{34}$

Meanwhile, as discussed earlier, some states have taken the lead, including poor states like Odisha under the Mamata scheme. Tamil Nadu has gone further, not only extending maternity benefits to two children but also raising the benefits to Rs. 14,000 per child aside from in-kind support worth Rs. 4,000 in the form of a "maternity nutrition kit".

As we saw, the centrally sponsored PMMVY scheme has not done very well so far. But there is no great difficulty in turning it around, by extending it to all births, raising the benefits, and simplifying the formalities. If Odisha and Tamil Nadu's experiences are any indication, this could easily become one of India's most successful and popular social security programmes.

\footnotetext{
33 The last figure is an estimate from the "revised Budget" for 2019-20 (see also Figure 1).

34 The matter is pending in the Supreme Court under the "right to food" case, but hearings keep being postponed or side-tracked.
} 


\section{References}

Arora, P. and Aeri, B. T. (2019). Gestational Weight Gain among Healthy Pregnant Women from Asia in comparison with Institute of Medicine (IOM) Guidelines-2009: A Systematic Review. Journal of Pregnancy, 2019.

Centre for Equity Studies (2016). Progress of Children Under Six. (New Delhi: CSE).

Chandra, J. (2020a). The Long Wait for Maternity Benefits. The Hindu, 8 Februrary.

Chandra, J. (2020b). One in Three Payments for Maternity Benefit Scheme Credited to Wrong Account. The Hindu, 23 Februrary.

Chhachhi, A. (1998). Who is Responsible for Maternity Benefit: State, Capital or Husband? Bombay Assembly Debates on Maternity Benefit Bill, 1929. Economic and Political Weekly, 30 May.

Citizens' Initiative for the Rights of Children Under Six (2006). Focus on Children Under Six. (New Delhi: Secretariat of the Right to Food Campaign).

Coffey, D. and Hathi, P. (2016a). Underweight and Pregnant: Designing Universal Maternity Entitlements to Improve Health. Indian Journal of Human Development, 10(2).

Coffey, D. and Hathi, P. (2016b). Maternity Entitlements for Healthier Babies. Ideas for India, 7 July.

Dasgupta, U. (2021). Community Action, with a Focus on Women's Well-being, Can Fight Malnutrition. The Hindu, 5 January.

Dhorajiwala, S., Drèze, J., and Wagner, N. (2019). A Bridge to Nowhere. The Hindu, 27 March.

Drèze, J. (2018). Hollowing out a Promise. Indian Express, 13 July.

Drèze, J. (2020). Give Children Weight. Indian Express, 17 December.

Drèze, J. and Khera, R. (2017). Recent Social Security Initiatives in India. World Development, 98.

Drèze, J. and Paikra, V. (2020). The Uneven Decline of Health Services Across States During the Lockdown. The Wire, 7 October.

Drèze, J. and Sen, A. (2013). An Uncertain Glory: India and Its Contradictions. (New Delhi: Penguin).

Falcao, V., Sachin, K., and Painkra, S. (2019a). How the Centre can Ensure Women Receive Maternity Benefits. The Wire, 22 July. 
Falcao, V., Sachin, K., and Painkra, S. (2019b). Chronic Gaps in Health and Justice. The Telegraph, 8 October.

Ghatak, M. and Muralidharan, K. (2020). An Inclusive Growth Dividend: Reframing the Role of Income Transfers in India's Anti-poverty Strategy. Working Paper 90, Centre for Effective Global Action, University of California, Berkeley.

Goel, K. and Khera, R. (2015). Public Health in North India, An Exploratory Study in Four States. Economic and Political Weekly, 23 May.

Goldstein, R., Abell, S., Ranasinha, S., Misso, M., Boyle, J., Black, M., Li, N., Hu, G., Corrado, F., Rode, L., Kim, Y., Haugen, M., Song, W., Kim, M., Bogaerts, A., Devlieger, R., Chung, J., and Teede, H. (2017). Association of Gestational Weight Gain with Maternal and Infant Outcomes. JAMA, 317(21).

Goli, S., Ganguly, D., Chakravorty, S., Siddiqui, M., Ram, H., Rammohan, A., and Acharya, S. (2019). Labour Room Violence in Uttar Pradesh, India: Evidence from Longitudinal Study of Pregnancy and Childbirth. BMJ Open, 9.

Government of India (2016). Economic Survey 2015-16. (New Delhi: Finance Ministry).

Government of India (2018). Pradhan Mantri Matru Vandana Yojana (PMMVY): Progress Report, September 2017 - August 2018. (New Delhi: Ministry of Women and Child Development).

Government of India (n.d.). My Safe Motherhood: Booklet for Expecting Mothers. (New Delhi: Ministry of Health Family Welfare).

Government of Maharashtra (2005). Dr. Babasaheb Ambedkar: Writings and Speeches. Vol. 2, second edition, edited by Hari Narke. (Mumbai: Higher and Technical Education Department).

Government of Tamil Nadu (2019). Policy Note 2019-20. (Chennai: Ministry of Health and Family Welfare).

Haaren, P. and Klonner, S. (2020). Maternal Cash for Better Child Health? The Impacts of India's IGMSY/PMMVY Maternity Benefit Scheme. Discussion Paper 689, Department of Economics, University of Heidelberg.

Haaren, P. and Klonner, S. (2021). Evaluating India's Maternal Cash Transfer Programmes. Ideas for India, 4 March.

Institute of Medicine (2009). Weight Gain During Pregnancy: Re-examining the Guidelines. (Washington DC: The National Academies Press).

International Institute for Population Sciences (2017a). National Family Health Survey (NFHS4) 2015-16: India. (Mumbai: IIPS). 
International Institute for Population Sciences (2017b). National Family Health Survey (NFHS4) 2015-16: Odisha. (Mumbai: IIPS).

International Institute for Population Sciences (2017c). National Family Health Survey (NFHS4) 2015-16: State Reports. (Mumbai: IIPS).

IPC-IG and UNDP (2016). Social Protection in Africa: Inventory of Non-Contributory Programmes. (Brasília: International Policy Centre for Inclusive Growth).

IPC-IG and UNICEF (2019). Social Protection in Asia and Pacific: Inventory of Non-Contributory Programmes. (Brasília: International Policy Centre for Inclusive Growth).

John, A., Nisbett, N., Barnett, I., Avula, R., and Menon, P. (2020). Factors Influencing the Performance of Community Health Workers: A Qualitative Study of Anganwadi Workers from Bihar, India. PLoS ONE, 15(11).

Kalra, A. and Priya, A. (2020). Birth Pangs: Universal Maternity Entitlements in India. Economic and Political Weekly, 23 August.

Khera, R. (2015). Child Development: Baby Steps in Odisha. Economic and Political Weekly, 3 October.

Khera, R. and Somanchi, A. (2020). Covid-19 and Aadhaar. EPW Engage, 25 April.

National Commission on Population (2020). Population Projections for India and States 20112036. (New Delhi: Government of India).

NITI Aayog (2019). Transforming Nutrition in India: POSHAN Abhiyaan. (New Delhi: NITI Aayog).

NITI Aayog (2020). Accelerating Progress on Nutrition in India: What Will It Take? (New Delhi: NITI Aayog).

Office of the Registrar General (2017). Sample Registration System Statistical Report 2017. (New Delhi: Government of India).

Office of the Registrar General (2018). Sample Registration System Statistical Report 2018. (New Delhi: Government of India).

Paikra, V. (2020). Correction Queues Trip Up Maternity Benefit Applicants In Chhattisgarh. IndiaSpend, 14 February.

Pant, L., Khalid, N., Sharma, K., and Srivastava, N. (2021). Disrespectful Maternity Care: Labour Room Violence in Government Health Facilities in India. Preprint, Research Institute for Compassionate Economics (r.i.c.e.).

Rajagopalan, S. and Tabarrok, A. (2019). Premature Imitation and India's Flailing State. The Independent Review, 24(2). 
Sharma, G., Penn-Kekana, L., Halder, K., and Philippi, V. (2019). An Investigation into Mistreatment of Women during Labour and Childbirth in Maternity Care Facilities in Uttar Pradesh, India. Reproductive Health, 16(7).

Singh, P. (2015). Subnationalism and Social Development: A Comparative Analysis of Indian States. World Politics, 63(7).

Singh, S., Doyle, P., Campbell, O., Ramana Rao, G., and Murthy, V. (2018). Pregnant Women who Requested a '108' Ambulance in Two States of India. BMJ Global Health, 3.

Strehlow, M., Newberry, J., Bills, C., Min, H., Evensen, A., Leeman, L., Pirrotta, E., Ramana Rao, G., and Mahadevan, S. (2016). Characteristics and Outcomes of Women using Emergency Medical Services for Third-trimester Pregnancy-related Problems in India: A Prospective Observational Study. BMJ Open, 6.

Tillin, L., Deshpande, R., and Kailash, K. (2016). Politics of Welfare: Comparisons across Indian States. (Oxford: OUP).

Uma, S. and Kamath, A. (2019). Gamechanger or a Trojan Horse: Some Reflections on India's Maternity Benefit Act, 1961. Economic and Political Weekly, 16 May. 
Table 1: Maternity Benefits in India: A Snapshot

\begin{tabular}{|c|c|c|c|c|}
\hline Law/Scheme & Entitlement & Funding & Eligibility & $\begin{array}{l}\text { Coverage } \\
(2018-19)\end{array}$ \\
\hline $\begin{array}{l}\text { Maternity Benefit Act, } 1961 \\
\text { (amended 2017) }^{a}\end{array}$ & $\begin{array}{l}\text { Up to } 26 \text { weeks paid } \\
\text { leave for first two } \\
\text { children; } 12 \text { weeks for } \\
\text { other children }\end{array}$ & Employer & $\begin{array}{l}\text { Women working in facto- } \\
\text { ries, mines, plantations, } \\
\text { and shops or establish- } \\
\text { ments with } 10 \text { or more } \\
\text { employees }\end{array}$ & $\begin{array}{l}\text { Small } \\
\text { (see Appendix) }\end{array}$ \\
\hline $\begin{array}{l}\text { Employees State Insurance } \\
\text { Act, } 1948\end{array}$ & $\begin{array}{l}\text { Up to } 26 \text { weeks paid } \\
\text { leave }\end{array}$ & Employer $^{b}$ & $\begin{array}{l}\text { Women whose establish- } \\
\text { ment is covered by ESI Act } \\
\text { and whose salary is below } \\
\text { Rs. } 21,000 \text { pm }\end{array}$ & 42,722 \\
\hline $\begin{array}{l}\text { National Food Security Act, } \\
2013\end{array}$ & Rs. 6,000 & Government & $\begin{array}{l}\text { All births (except those } \\
\text { already covered in the for- } \\
\text { mal sector) }\end{array}$ & See PMMVY \\
\hline $\begin{array}{l}\text { Pradhan Mantri Matru } \\
\text { Vandana Yojana, } 2017\end{array}$ & $\begin{array}{l}\text { Rs. } 5,000 \text {, in three } \\
\text { instalments }\end{array}$ & $\begin{array}{l}\text { Government, } \\
\text { 60:40 sharing } \\
\text { between centre } \\
\text { and state } \\
\end{array}$ & All women, first child only & 67.3 lakh $^{c}$ \\
\hline $\begin{array}{l}\text { Mamata scheme, } 2011 \\
\text { (Odisha) }\end{array}$ & $\begin{array}{l}\text { Rs. } 5,000 \text {, in two } \\
\text { instalments }\end{array}$ & State government & $\begin{array}{l}\text { All women (except govt. } \\
\text { employees and wives of } \\
\text { govt. employees), first two } \\
\text { births }{ }^{d}\end{array}$ & 4.99 lakh \\
\hline $\begin{array}{l}\text { Dr. Muthulakshmi Reddy } \\
\text { scheme, } 1987 \text { (Tamil Nadu) }\end{array}$ & $\begin{array}{l}\text { Rs. } 14,000 \text { cash, in five } \\
\text { instalments }\end{array}$ & $\begin{array}{l}\text { State and central } \\
\text { governments }\end{array}$ & $\begin{array}{l}\text { Poor women, first two } \\
\text { births }\end{array}$ & $7.06 \mathrm{lakh}^{c}$ \\
\hline $\begin{array}{l}\text { KCR Ammavodi scheme, } \\
2017 \text { (Telangana) }\end{array}$ & $\begin{array}{l}\text { Rs. } 12,000 \text { ( } 13,000 \text { for } \\
\text { girl child) cash, in four } \\
\text { instalments }\end{array}$ & $\begin{array}{l}\text { State and central } \\
\text { governments }\end{array}$ & All women, first two births & $\mathrm{n} / \mathrm{a}$ \\
\hline
\end{tabular}




\section{Table 1 (cont'd)}

$a$ - As mentioned in the text, this Act has recently been superseded (with similar provisions) by the Code on Social Security, 2020. For government employees, benefits are specified by the relevant "service rules".

$b$ - The proposal for a government scheme to reimburse 7 weeks' paid leave to employers who provide the full 26 weeks of maternity leave to female employees not covered by ESI Act (salary less than Rs. 15,000pm but registered with EPFO for a year at least) is yet to be adopted (see https: / / rb.gy/7jgxju).

$c$ - Including a small number of women in Tamil Nadu who receive PMMVY benefits.

$d$ - The two-children limit does not apply to women who belong to "particularly vulnerable tribal groups" (PVTGs).

Note: This table is not exhaustive - see Appendix for further details as well as sources of the coverage estimates (last column). 
Table 2: All-India PMMVY Coverage*

\begin{tabular}{lccc}
\hline & $\mathbf{2 0 1 7 - 1 8}$ & $\mathbf{2 0 1 8 - 1 9}$ & $\mathbf{2 0 1 9 - 2 0}$ \\
\hline $\begin{array}{l}\text { Number of PMMY beneficiaries (lakh) } \\
\quad \text { At least one instalment }\end{array}$ & 11.1 & 65.4 & 91.2 \\
$\quad$ Third instalment & - & 31.9 & 55.8 \\
\hline $\begin{array}{l}\text { Estimated PMMVY coverage, as \% of first births: } \\
\quad \text { At least one instalment }\end{array}$ & 10 & 57 & 78 \\
$\quad$ Third instalment & - & 28 & 48 \\
\hline $\begin{array}{l}\text { Estimated PMMVY coverage, as \% of all births: } \\
\text { At least one instalment }\end{array}$ & 5 & 28 & 39 \\
$\quad$ Third instalment & - & 14 & 24 \\
\hline
\end{tabular}

* Excluding Odisha, Tamil Nadu and Telangana where state-specific schemes apply (see text).

Sources: Absolute numbers of PMMVY beneficiaries were obtained from responses to a question in the Lok Sabha and to RTI queries (see Appendix). Absolute numbers of births were calculated using projected population figures for 2017, 2018, and 2019 (National Commission on Population, 2020, Table 8) and corresponding birth rates from Office of the Registrar General $(2017,2018)$, Statement 14 . The share of first births in all live births was obtained from the same source, Statement 35. In the absence of birth data for 2019, we used 2018 birth data for the 2019-20 calculations. 
Table 3a: The JABS Sample

\begin{tabular}{llccc}
\hline & Survey & \multicolumn{3}{c}{ Number of women in the sample } \\
& $\begin{array}{l}\text { month } \\
(\mathbf{2 0 1 9 )}\end{array}$ & $\begin{array}{c}\text { Pregnant } \\
\text { women }\end{array}$ & $\begin{array}{c}\text { Nursing } \\
\text { women }\end{array}$ & All women \\
\hline Chhattisgarh & June & 67 & 59 & 126 \\
\hline Himachal Pradesh & July & 70 & 68 & 138 \\
\hline Jharkhand & October & 26 & 49 & 75 \\
\hline Madhya Pradesh & June & 58 & 53 & 111 \\
\hline Odisha & June & 57 & 66 & 123 \\
\hline Uttar Pradesh & June & 64 & 69 & 133 \\
\hline All States & & $\mathbf{3 4 2}$ & $\mathbf{3 6 4}$ & $\mathbf{7 0 6}$
\end{tabular}

* Women who delivered a baby during the six months preceding the survey, as per local anganwadi records. 
Table 3b: Characteristics of Sample Households and Individual Respondents

\begin{tabular}{|c|c|c|}
\hline & $\begin{array}{c}\text { Pregnant } \\
\text { women }\end{array}$ & $\begin{array}{l}\text { Nursing } \\
\text { women }^{a}\end{array}$ \\
\hline \multicolumn{3}{|c|}{ Household characteristics } \\
\hline Average household size & 5.4 & 6.5 \\
\hline \multicolumn{3}{|l|}{ Household type $(\%)$ : } \\
\hline Nuclear family & 32 & 29 \\
\hline Nuclear family, with dependents & 25 & 24 \\
\hline Joint family & 44 & 47 \\
\hline \multicolumn{3}{|l|}{ Social category $(\%)$ : } \\
\hline Scheduled caste (SC) & 19 & 16 \\
\hline Scheduled tribe (ST) & 44 & 50 \\
\hline "Other backward classes" (OBC) & 26 & 23 \\
\hline Other & 12 & 12 \\
\hline Average agricultural land owned (acres) & 1.2 & 1.8 \\
\hline \multicolumn{3}{|l|}{ Possession of following assets $(\%)$ : } \\
\hline Fan & 53 & 56 \\
\hline Toilet & 63 & 61 \\
\hline Motorbike & 37 & 37 \\
\hline Television & 50 & 46 \\
\hline Smartphone & 42 & 41 \\
\hline \multicolumn{3}{|c|}{ Respondent characteristics } \\
\hline Average age (years) & 24.4 & 24.7 \\
\hline Average age at marriage (years) & 18.8 & 19.4 \\
\hline Average number of living children & $1^{b}$ & $2^{b}$ \\
\hline Average years of school/college & 7.7 & 8 \\
\hline \multicolumn{3}{|l|}{ Literacy status $(\%)$ : } \\
\hline Reads fluently & 54 & 55 \\
\hline Reads a little & 20 & 22 \\
\hline Unable to read & 26 & 23 \\
\hline \multicolumn{3}{|l|}{ Primary occupations ${ }^{c}(\%):$} \\
\hline Homemaker & 78 & 75 \\
\hline Agricultural self-employment & 60 & 65 \\
\hline Casual agricultural labour & 18 & 19 \\
\hline Casual non-agricultural labour & 10 & 8 \\
\hline Non-agricultural self-employment & 3 & 3 \\
\hline Regular employment & 3 & 1 \\
\hline Contract worker & 2 & 2 \\
\hline Other & 5 & 3 \\
\hline
\end{tabular}

$a$ - Women who delivered a baby during the six months preceding the survey.

$b$ - Strictly speaking, 0.9 and 1.9 respectively.

$c$ - Respondents were asked to report one or two primary occupations.

Source: JABS survey. 
Table 4: JABS Survey: Selected Findings

\begin{tabular}{|c|c|c|}
\hline & $\begin{array}{l}\text { Nursing } \\
\text { women }\end{array}$ & $\begin{array}{c}\text { Pregnant } \\
\text { women }\end{array}$ \\
\hline \multicolumn{3}{|l|}{ Pregnancy } \\
\hline Average weight gain during pregnancy $(\mathrm{kg})$ & 7.0 & - \\
\hline \multicolumn{3}{|l|}{ Proportion (\%) of women who were: } \\
\hline Eating less during pregnancy & 47 & 49 \\
\hline Eating more during pregnancy & 22 & 23 \\
\hline Eating nutritious food more often during pregnancy & 31 & 24 \\
\hline Eating nutritious food every day during pregnancy & 20 & 22 \\
\hline \multicolumn{3}{|l|}{$\begin{array}{l}\text { Proportion (\%) of women who had symptoms of weakness } \\
\text { during pregnancy: }\end{array}$} \\
\hline Swollen feet & 41 & 26 \\
\hline Impairment of daylight vision & 17 & 19 \\
\hline Convulsions & 9 & 8 \\
\hline \multicolumn{3}{|l|}{ Proportion (\%) of women who: } \\
\hline Worked on family farms during pregnancy & 20 & 18 \\
\hline Had no one to help with housework during pregnancy & 21 & 26 \\
\hline Felt they did not get enough rest during pregnancy & 38 & 30 \\
\hline Were able to take complete rest before delivery & 37 & - \\
\hline $\begin{array}{l}\text { Proportion (\%) of women who faced serious problems during } \\
\text { pregnancy for lack of money }\end{array}$ & 30 & 34 \\
\hline \multicolumn{3}{|l|}{ Delivery } \\
\hline Proportion of women who delivered their child at home (\%) & 12 & - \\
\hline $\begin{array}{l}\text { Proportion of households that had to borrow or sell assets to } \\
\text { meet delivery expenses (\%) }\end{array}$ & 30 & - \\
\hline
\end{tabular}

\section{ICDS, Health Services and PMMVY}

Proportion of women who received the following services from the local AWC or PHC during pregnancy (\%):

At least one health check-up 86

Tetanus shots 96

Iron and folid acid tablets

Proportion of eligible women who applied for PMMVY ${ }^{a}(\%)$

93

74

72

$a$ - Read Mamata scheme, in the case of Odisha.

Source: JABS survey. Figures for nursing women apply to the most recent pregnancy. 
Table 5: Access to Health Services among Nursing Women

\begin{tabular}{lc}
\hline Place of delivery (\%): & \\
Public health institution & 81 \\
Private health institution & 7 \\
Home (in-laws or maika) & 12 \\
\hline Attitude of staff, if delivered at institution (\%): & \\
Friendly and helpful & 61 \\
Somewhat helpful & 17 \\
Indifferent & 10 \\
Careless & 3 \\
Rude or hostile & 8 \\
\hline Amount spent on last delivery (Rs.) & \\
Public institution & 3,643 \\
Private institution & 45,524 \\
Home delivery & 1,697 \\
All deliveries & 6,409 \\
\hline Use of ambulance service for delivery (\%): & 60 \\
Used & 12 \\
Tried, without success & 28 \\
Did not try & 58 \\
\hline If used ambulance, average amount paid (Rs.) & 86 \\
\hline Received the following services from AWC/PHC during pregnancy (\%): \\
At least one health check-up & 96 \\
Tetanus shot & 93 \\
Iron and folic acid tablets & 92 \\
Food supplements & 75 \\
Advice related to pregnancy/diet/delivery & 71 \\
Post-natal check-up & 14 \\
\hline Health insurance (\%): & 9 \\
Yes, RSBY & 61 \\
Yes, Ayushman Bharat & \\
Yes, State scheme & \\
Yes, Other & \\
No & \\
\hline & \\
\hline
\end{tabular}

Source: JABS survey. Figures apply to most recent pregnancy. 
Table 6: Correlates of Weight Gain During Pregnancy (OLS)

(Dependent variable: average monthly weight gain, in grams)

\begin{tabular}{|c|c|c|c|c|c|c|}
\hline & (1) & $(2)$ & (3) & (4) & (5) & (6) \\
\hline & \multicolumn{2}{|c|}{$\begin{array}{c}\text { Individual } \\
\text { characteristics only }\end{array}$} & \multicolumn{2}{|c|}{$\begin{array}{c}\text { Expanded } \\
\text { characteristics } \\
\text { (+ food quantity })\end{array}$} & \multicolumn{2}{|c|}{$\begin{array}{c}\text { Expanded } \\
\text { characteristics } \\
(+ \text { nutritious food })\end{array}$} \\
\hline & $\begin{array}{l}\text { Nursing } \\
\text { women }\end{array}$ & $\begin{array}{l}\text { Pooled } \\
\text { sample }\end{array}$ & $\begin{array}{l}\text { Nursing } \\
\text { women }\end{array}$ & $\begin{array}{l}\text { Pooled } \\
\text { sample }\end{array}$ & $\begin{array}{l}\text { Nursing } \\
\text { women }\end{array}$ & $\begin{array}{l}\text { Pooled } \\
\text { sample }\end{array}$ \\
\hline \multicolumn{7}{|l|}{ Individual characteristics } \\
\hline Age (years) & $\begin{array}{l}10.71^{*} \\
(6.32)\end{array}$ & $\begin{array}{l}11.82^{\star *} \\
(4.85)\end{array}$ & $\begin{array}{c}5.59 \\
(5.87)\end{array}$ & $\begin{array}{c}6.23 \\
(4.73)\end{array}$ & $\begin{array}{c}5.99 \\
(5.84)\end{array}$ & $\begin{array}{c}5.77 \\
(4.43)\end{array}$ \\
\hline Years of formal education & $\begin{array}{c}22.56^{* * *} \\
(5.63)\end{array}$ & $\begin{array}{l}22.15^{* * *} \\
(5.83)\end{array}$ & $\begin{array}{l}9.19^{*} \\
(4.72)\end{array}$ & $\begin{array}{l}11.79^{* *} \\
(5.48)\end{array}$ & $\begin{array}{l}10.61^{* *} \\
(4.84)\end{array}$ & $\begin{array}{l}13.42^{* *} \\
(5.60)\end{array}$ \\
\hline Does casual labor (dummy) & $\begin{array}{c}-127.39^{*} \\
(64.80)\end{array}$ & $\begin{array}{c}-147.11^{\star * *} \\
(53.84)\end{array}$ & $\begin{array}{l}-81.23 \\
(57.66)\end{array}$ & $\begin{array}{c}-139.24^{* * *} \\
(49.24)\end{array}$ & $\begin{array}{l}-76.64 \\
(59.27)\end{array}$ & $\begin{array}{l}-125.33^{* *} \\
(49.30)\end{array}$ \\
\hline \multicolumn{7}{|l|}{ Household characteristics } \\
\hline Household size & & & $\begin{array}{r}-15.49 \\
(9.55)\end{array}$ & $\begin{array}{c}-17.04^{* *} \\
(7.23)\end{array}$ & $\begin{array}{r}-12.03 \\
(9.56)\end{array}$ & $\begin{array}{c}-15.26^{* *} \\
(7.37)\end{array}$ \\
\hline SC/ST household (dummy) & & & $\begin{array}{l}-51.58 \\
(77.91)\end{array}$ & $\begin{array}{l}-49.64 \\
(65.91)\end{array}$ & $\begin{array}{l}-31.83 \\
(73.25)\end{array}$ & $\begin{array}{l}-31.29 \\
(63.72)\end{array}$ \\
\hline Asset index & & & $\begin{array}{c}17.87^{\star * *} \\
(5.90)\end{array}$ & $\begin{array}{c}11.08^{* *} \\
(5.45)\end{array}$ & $\begin{array}{l}15.48^{\star *} \\
(5.42)\end{array}$ & $\begin{array}{l}8.97^{\star} \\
(5.06)\end{array}$ \\
\hline \multicolumn{7}{|l|}{ Pregnancy experience } \\
\hline $\begin{array}{l}\text { Got enough rest } \\
\text { (self-reported, dummy) }\end{array}$ & $\begin{array}{l}219.48^{* * *} \\
(66.12)\end{array}$ & $\begin{array}{l}212.55^{\star * *} \\
(53.98)\end{array}$ & $\begin{array}{l}127.87^{* *} \\
(61.26)\end{array}$ & $\begin{array}{c}139.26^{* * *} \\
(48.26)\end{array}$ & $\begin{array}{l}111.46^{*} \\
(62.15)\end{array}$ & $\begin{array}{l}126.39^{* *} \\
(50.19)\end{array}$ \\
\hline \multicolumn{7}{|l|}{$\begin{array}{l}\text { Food intake } \\
\text { [Default: more than usual] }\end{array}$} \\
\hline Same as usual & & & $\begin{array}{l}-81.43 \\
(79.97)\end{array}$ & $\begin{array}{l}-57.58 \\
(64.86)\end{array}$ & & \\
\hline Less than usual & & & $\begin{array}{r}-137.78^{*} \\
(76.90)\end{array}$ & $\begin{array}{l}-88.95 \\
(56.41)\end{array}$ & & \\
\hline \multicolumn{7}{|l|}{$\begin{array}{l}\text { Freq. of nutritious food } \\
\text { [Default: regularly] }\end{array}$} \\
\hline Occasionally & & & & & $\begin{array}{c}-133.87^{* *} \\
(64.81)\end{array}$ & $\begin{array}{l}-123.89^{* *} \\
(52.22)\end{array}$ \\
\hline Never & & & & & $\begin{array}{c}-57.88 \\
(124.82)\end{array}$ & $\begin{array}{c}11.59 \\
(113.01)\end{array}$ \\
\hline Dummy for "leader state" & & & $\begin{array}{l}158.61^{\star *} \\
(76.71)\end{array}$ & $\begin{array}{c}174.19^{* * *} \\
(61.67)\end{array}$ & $\begin{array}{l}157.94^{* *} \\
(79.05)\end{array}$ & $\begin{array}{l}176.19^{* * *} \\
(61.77)\end{array}$ \\
\hline Constant & $\begin{array}{c}179.29 \\
(163.88)\end{array}$ & $\begin{array}{l}324.13 \\
(228.28)\end{array}$ & $\begin{array}{l}420.73^{* *} \\
(195.57)\end{array}$ & $\begin{array}{l}486.41^{*} \\
(252.09)\end{array}$ & $\begin{array}{l}371.52^{*} \\
(199.42)\end{array}$ & $\begin{array}{l}487.92^{* *} \\
(231.52)\end{array}$ \\
\hline Observations & 248 & 414 & 243 & 407 & 247 & 412 \\
\hline R-squared & 0.15 & 0.15 & 0.26 & 0.22 & 0.26 & 0.23 \\
\hline
\end{tabular}




\section{Table 6 (cont'd)}

${ }^{*} \mathrm{p}<0.1,{ }^{* *} \mathrm{p}<0.05,{ }^{* *} \mathrm{p}<0.01$ (clustered standard errors in parentheses).

Note: "Pooled sample" consists of nursing women and also pregnant women with at least four months of pregnancy. In the pooled sample, there is a separate dummy (not shown) for each month of pregnancy from 5 to 9 (with 4 as the default). On the "leader states" (Chhattisgarh, HP and Odisha), see next section. The asset index (ranging 0 to 25) is a simple sum of nine scores: 1 each for fan and feature phone, 2 each for smartphone and gas stove, 3 each for television and cooler, 4 each for toilet and motorcycle, 5 for ownership of at least five acres of land. 
Table 7: Leaders and Laggards

\begin{tabular}{|c|c|c|c|c|}
\hline & $\begin{array}{c}\text { Uttar } \\
\text { Pradesh }\end{array}$ & $\underset{a}{\text { Laggards }}$ & $\begin{array}{c}\text { Leaders } \\
b\end{array}$ & $\begin{array}{l}\text { Himachal } \\
\text { Pradesh }\end{array}$ \\
\hline \multicolumn{5}{|c|}{ Socio-economic status } \\
\hline Proportion of women who were unable to read (\%) & 39 & 32 & 16 & 4 \\
\hline Average years of school/college education & 6 & 7 & 9 & 12 \\
\hline Average age at marriage (years) & 18 & 18 & 21 & 22 \\
\hline Average number of living children & 2.4 & 2.1 & 1.8 & 1.6 \\
\hline Proportion of households with a toilet (\%) & 36 & 42 & 79 & 93 \\
\hline \multicolumn{5}{|l|}{ Pregnancy } \\
\hline Average weight gain during pregnancy $(\mathrm{kg})$ & 4 & 5 & 9 & 11 \\
\hline \multicolumn{5}{|l|}{$\begin{array}{l}\text { Proportion (\%) of women who, during their pregnancy, } \\
\text { were eating: }\end{array}$} \\
\hline Less than usual & 74 & 59 & 35 & 21 \\
\hline Nutritious food more often than usual & 15 & 25 & 37 & 55 \\
\hline Nutritious food every day & 6 & 10 & 29 & 62 \\
\hline \multicolumn{5}{|l|}{$\begin{array}{l}\text { Proportion (\%) of women who had symptoms of weak- } \\
\text { ness during pregnancy: }\end{array}$} \\
\hline Swollen feet & 49 & 47 & 35 & 37 \\
\hline Impairment of daylight vision & 27 & 20 & 15 & 7 \\
\hline Convulsions & 10 & 9 & 8 & 4 \\
\hline \multicolumn{5}{|l|}{ Proportion (\%) of women who, during pregnancy: } \\
\hline Worked on family farms & 39 & 28 & 13 & 18 \\
\hline Had no-one to help with housework & 28 & 25 & 17 & 4 \\
\hline Felt they did not get enough rest & 54 & 57 & 21 & 9 \\
\hline $\begin{array}{l}\text { Proportion of women who faced serious problems dur- } \\
\text { ing pregnancy for lack of money }(\%)\end{array}$ & 64 & 44 & 18 & 12 \\
\hline \multicolumn{5}{|l|}{ Delivery } \\
\hline $\begin{array}{l}\text { Proportion of women who delivered their last child at } \\
\text { home }(\%)\end{array}$ & 35 & 19 & 6 & 6 \\
\hline $\begin{array}{l}\text { Proportion of households that had to borrow or sold } \\
\text { assets to meet delivery expenses }(\%)\end{array}$ & 51 & 43 & 19 & 13 \\
\hline
\end{tabular}

Proportion (\%) of women who received the following services from the local AWC or PHC:

At least one health check-up

Tetanus shots

Iron and folic acid tablets

Food supplements

Advice related to pregnancy/diet/delivery

At least one post-natal check-up 64 $\begin{array}{llll}64 & 80 & 91 & 88\end{array}$ $\begin{array}{llll}87 & 93 & 98 & 97\end{array}$ $\begin{array}{llll}84 & 91 & 94 & 88\end{array}$ $\begin{array}{llll}84 & 89 & 94 & 94\end{array}$

$\begin{array}{llll}46 & 61 & 87 & 79\end{array}$

Proportion (\%) of eligible women applied for PMMVY

54

46

63

79

66

$a$ - Jharkhand, Madhya Pradesh, Uttar Pradesh

53

82
90

Source: JABS survey (nursing women only). 
Table 8: Care during Pregnancy in Rural India, 2015-16 (NFHS-4)

\begin{tabular}{|c|c|c|c|c|}
\hline & $\begin{array}{l}\text { Himachal } \\
\text { Pradesh }\end{array}$ & $\begin{array}{c}\text { Uttar } \\
\text { Pradesh }\end{array}$ & $\begin{array}{c}\text { JABS } \\
\text { states }\end{array}$ & India \\
\hline Pregnancy was registered $(\%)$ & 94 & 79 & 83 & 85 \\
\hline Woman received MCP card (if registered) (\%) & 95 & 82 & 87 & 90 \\
\hline Woman was weighed during pregnancy (\%) & 93 & 60 & 76 & 88 \\
\hline Received all recommended ante-natal care $(\%)^{b}$ & 36 & 4 & 9 & 17 \\
\hline \multicolumn{5}{|l|}{ Had symptoms of weakness during pregnancy (\%): } \\
\hline Difficulty with daylight vision & 5 & 15 & 14 & 12 \\
\hline Convulsions (not from fever) & 10 & 31 & 26 & 18 \\
\hline Swelling (face, body, legs) & 26 & 34 & 34 & 31 \\
\hline Public health facility delivery $(\%)^{c}$ & 61 & 48 & 56 & 54 \\
\hline Private facility delivery $(\%)^{c}$ & 14 & 19 & 14 & 20 \\
\hline Cost at private facility (Rs.) & 19,381 & 14,475 & 13,820 & 15,034 \\
\hline Had to borrow to meet delivery expenses (\%) & 7 & 29 & 28 & 26 \\
\hline
\end{tabular}

$a$ - Population-weighted averages of state-specific figures for Chhattisgarh, Himachal Pradesh, Jharkhand, Madhya Pradesh, Odisha and Uttar Pradesh (using 2011 census population figures).

$b$ - Four or more antenatal checks, at least one tetanus toxoid injection, and consumed iron and folic acid tablets/syrup for 100 days or more.

$c$ - Base: All live births in the five years preceding the survey.

Source: International Institute for Population Sciences (2017c), Tables 43, 45, 47 for state-wise estimates and International Institute for Population Sciences (2017a), Tables 8.1, 8.2, 8.13, 8.20 for all-India estimates. The following indicators were calculated from unit-record data: "weighed during pregnancy", "received all recommended types of antenatal care", "symptoms of weakness" (state-wise estimates), and "had to borrow to meet delivery expenses". Unless stated otherwise, figures are based on the most recent live birth; they all refer to women who had a live birth in the preceding five years. 
Table 9: Coverage of maternity benefits - JABS survey

\begin{tabular}{lcccc}
\hline & $\begin{array}{c}\text { Pregnant women } \\
\text { (3rd trimester) }\end{array}$ & \multicolumn{2}{c}{ Nursing women } \\
& $\begin{array}{c}\text { JABS states } \\
\text { excluding } \\
\text { Odisha } \\
(\text { PMMVY) }\end{array}$ & $\begin{array}{c}\text { Odisha } \\
\text { (Mamata) }\end{array}$ & $\begin{array}{c}\text { JABS states } \\
\text { excluding } \\
\text { Odisha } \\
(\text { PMMVY) }\end{array}$ & $\begin{array}{c}\text { Odisha } \\
\text { (Mamata) }\end{array}$ \\
\hline Eligible for maternity benefits ${ }^{a}(\%)$ & 43 & 95 & 50 & 89 \\
\hline Aware of maternity benefits (\%) & 61 & 95 & 65 & 91 \\
\hline $\begin{array}{l}\text { Applied for maternity benefits, among } \\
\text { those eligible (\%) }\end{array}$ & 48 & 89 & 65 & 88 \\
\hline $\begin{array}{l}\text { Received some benefits, among eligible (\%): } \\
\text { First instalment } \\
\text { Second instalment }{ }^{b}\end{array}$ & 8 & 37 & 28 & 75 \\
\hline $\begin{array}{l}\text { Received some benefits, among all } \\
\text { respondents (\%): }\end{array}$ & 2 & 0 & 21 & 7 \\
\hline
\end{tabular}

$a$ - "Eligible" means first birth, except in Odisha where second births are also eligible (the "mother's age" criterion is ignored as very few pregnant or nursing women were under-age).

$b$ - Under PMMVY, women are supposed to receive the second instalment before the end of pregnancy (and a third instalment later on). In Odisha, there are only two instalments, and the second instalment is generally disbursed later than 6 months after delivery - beyond the JABS survey's time frame.

Source: JABS survey. 
Table 10a: Application-related Difficulties Reported by Women

Proportion (\%) of nursing women who faced the following problems, among those who applied for PMMVY:

\begin{tabular}{lc}
\hline AWW is not cooperating & 7 \\
\hline AWW asked for money & 13 \\
\hline Lack of information & 15 \\
\hline Address on Aadhaar card was/is maika's & 18 \\
\hline Form submitted but nothing happened after wards & 19 \\
\hline Any of these issues & 41
\end{tabular}

Source: JABS survey.

Table 10b: Application-related Difficulties Reported by Anganwadi Workers

\begin{tabular}{lcc}
\hline & \multicolumn{2}{c}{$\begin{array}{c}\text { Proportion (\%) of AWWs who } \\
\text { reported various difficulties } \\
\text { being faced by: }\end{array}$} \\
\hline Supporting documents are difficult to arrange & Applicants & AWW $^{a}$ \\
\hline Aadhaar-related difficulties & 44 & - \\
\hline Bank-related difficulties & 53 & 44 \\
\hline Other difficulties & $\mathrm{n} / \mathrm{a}$ & 20 \\
\hline
\end{tabular}

$a$ - Based on the respondent's own experience.

Source: JABS survey. 
Table 11a: Utilization of ICDS Services in JABS states, 2015-16: Child Development

\begin{tabular}{|c|c|c|c|c|c|}
\hline \multicolumn{6}{|c|}{ Proportion of children under six years who received the following services (\%) } \\
\hline States & $\begin{array}{c}\text { Any ICDS } \\
\text { service }\end{array}$ & $\begin{array}{c}\text { Food } \\
\text { supplements }\end{array}$ & $\begin{array}{l}\text { Immuni- } \\
\text { zation }^{a}\end{array}$ & $\begin{array}{c}\text { Health } \\
\text { check-up }\end{array}$ & $\begin{array}{l}\text { Pre-school } \\
\text { education } b\end{array}$ \\
\hline Odisha & 78 & 75 & 61 & 66 & 61 \\
\hline Chhattisgarh & 77 & 72 & 63 & 68 & 55 \\
\hline Himachal Pradesh & 69 & 68 & 18 & 37 & 36 \\
\hline Madhya Pradesh & 63 & 60 & 50 & 52 & 42 \\
\hline Jharkhand & 55 & 51 & 43 & 33 & 30 \\
\hline Uttar Pradesh & 39 & 30 & 29 & 19 & 19 \\
\hline JABS States $^{c}$ & 52 & 46 & 40 & 36 & 32 \\
\hline All-India & 54 & 48 & 40 & 40 & 38 \\
\hline
\end{tabular}

$a$ - In HP and UP, immunization services are normally provided through the Health Department (ASHA workers, in the case of UP).

$b$ - Children aged $36-71$ months.

c- Population-weighted averages, using 2011 census population figures.

Source: NFHS-4 (International Institute for Population Sciences, 2017a), Table 9.19. States are ranked in descending order of the first indicator. 
Table 11b: Utilization of ICDS Services in JABS states, 2015-16: Maternal Care

\begin{tabular}{|c|c|c|c|c|c|c|}
\hline \multicolumn{7}{|c|}{ Proportion of mothers of children under six years who received the following services $(\%)$} \\
\hline & \multicolumn{3}{|c|}{ During Pregnancy } & \multicolumn{3}{|c|}{ During breastfeeding } \\
\hline State & $\begin{array}{c}\text { Any ICDS } \\
\text { service }^{a}\end{array}$ & $\begin{array}{c}\text { Food } \\
\text { supplements }\end{array}$ & $\begin{array}{c}\text { Health } \\
\text { check-up }\end{array}$ & $\begin{array}{c}\text { Any ICDS } \\
\text { service }^{a}\end{array}$ & $\begin{array}{c}\text { Food } \\
\text { supplements }\end{array}$ & $\begin{array}{c}\text { Health } \\
\text { check-up }\end{array}$ \\
\hline Chhattisgarh & 89 & 88 & 81 & 87 & 87 & 73 \\
\hline Odisha & 88 & 88 & 83 & 85 & 85 & 79 \\
\hline Himachal Pradesh & 78 & 78 & 37 & 66 & 66 & 31 \\
\hline Madhya Pradesh & 71 & 70 & 62 & 66 & 65 & 54 \\
\hline Jharkhand & 70 & 68 & 49 & 65 & 64 & 39 \\
\hline Uttar Pradesh & 39 & 35 & 24 & 31 & 29 & 16 \\
\hline JABS states ${ }^{b}$ & 57 & 54 & 44 & 51 & 50 & 36 \\
\hline All-India & 54 & 51 & 43 & 49 & 48 & 37 \\
\hline
\end{tabular}

$a$ - Inferred (by subtraction from 100\%) from the proportion who received "no services".

b - Population-weighted averages, using 2011 census population figures.

Source: NFHS-4 (International Institute for Population Sciences, 2017a), Table 9.21. States are ranked in descending order of the first indicator. 
Figure 1: PMMVY Budget versus Requirement for Universal Coverage

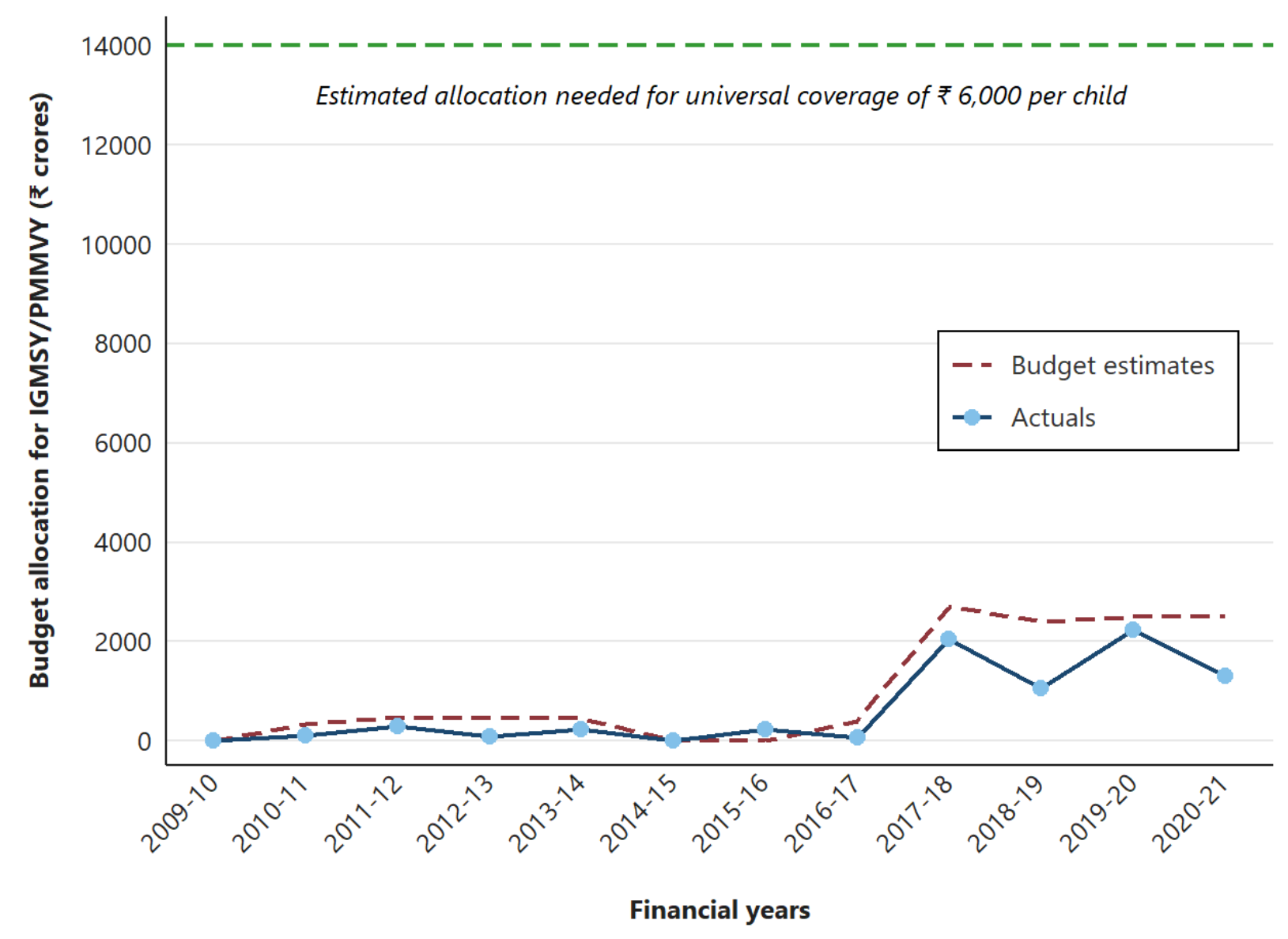

Notes: (1) For 2020-21, "revised estimates" are used as a proxy for "actuals" since the latter are yet to be released. (2) Indira Gandhi Matritva Sahyog Yojana (IGMSY) was launched in 2010 on a pilot basis in 53 districts. The NFSA 2013 made maternity benefits of Rs. 6,000 a legal entitlement for all pregnant women. PMMVY replaced IGMSY in 2017-18. (3) See footnote 3 and text for the basis of the universal coverage estimate.

Source: Budget expenditure documents from the annual Union Budget, Government of India. 
Figure 2: Weight Gain during Pregnancy in JABS Sample versus IoM Norms

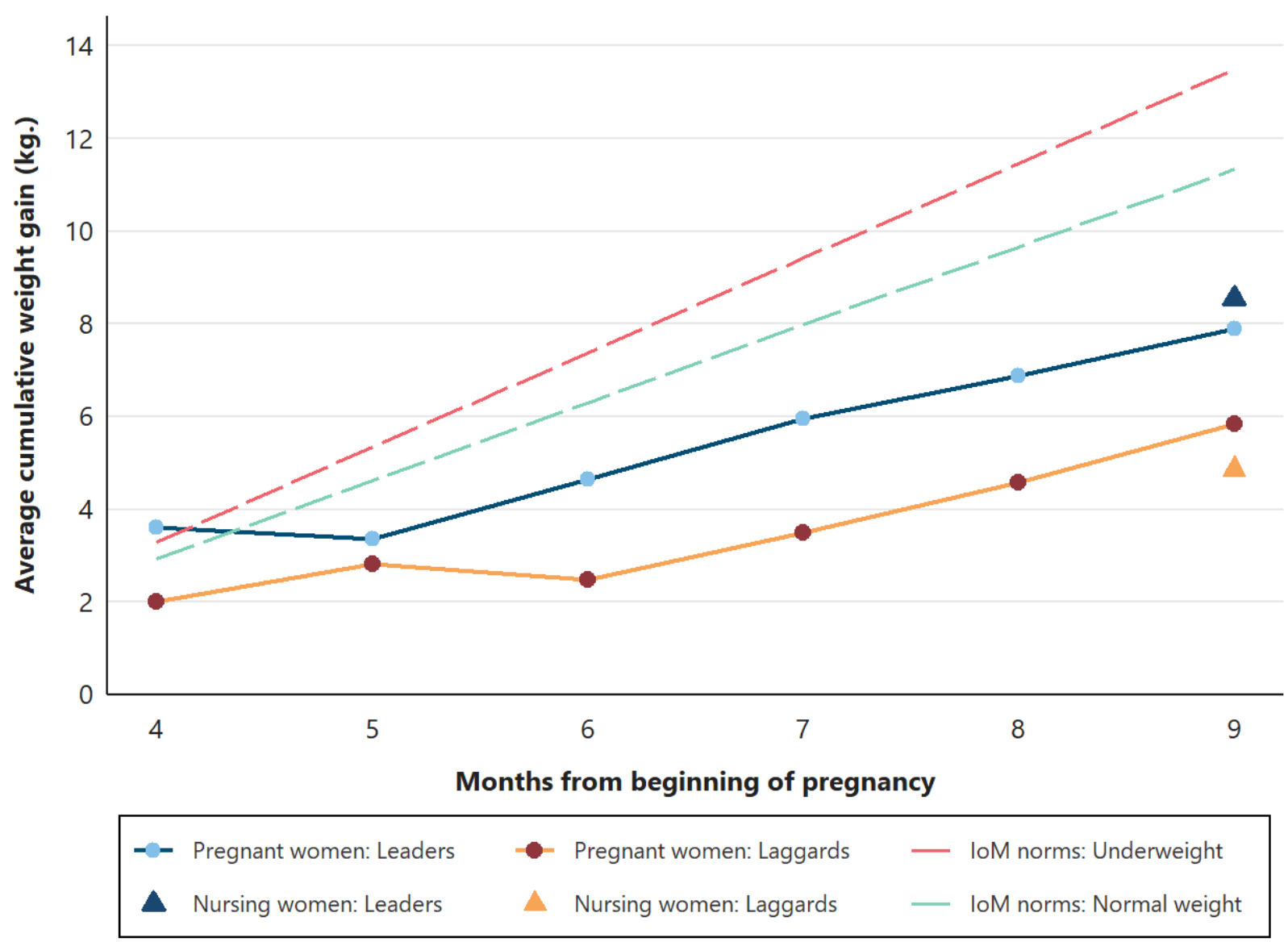

Notes: Leaders: Chhattisgarh, Himachal Pradesh, Odisha. Laggards: Jharkhand, Madhya Pradesh, Uttar Pradesh. This classification, discussed further in the text (section 4), is not based on weight gain.

Source: JABS survey for weight gain and Institute of Medicine (2009), Table S-1 for norms (mean of the recommended range of weight gain, assuming a weight gain of $1.25 \mathrm{~kg}$ in the first trimester). As discussed in the text (footnote 12), the norms should be considered as illustrative. 


\section{Appendix: Coverage of Maternity Benefits}

As Table 1 indicates, maternity benefits in India come under the ambit of a number of laws and schemes. This Appendix presents the sources of our coverage estimates in Tables 1 and 2 ("coverage" here refers to actual benefits, not entitlements or targets). Unless stated otherwise, the reference year is 2018-19.

\section{PMMVY}

2017-18: Response to question in Lok Sabha (starred question no. 256 dated 28/12/2018, available at https://rb.gy/pu1wwb).

2018-19 and 2019-20: Responses to RTI queries from the Ministry of Women and Child Development (dated 28/10/2019 and 24/08/2020 respectively).

\section{State Schemes}

Mamata scheme (Odisha): Personal communication from the Department of Women and Child Development and Mission Shakti, Government of Odisha (cumulative numbers of beneficiaries are available from annual Budget Speeches - see https:// rb.gy/57o03d). The Mamata scheme is funded by the state government.

Dr. Muthulakshmi Reddy scheme (Tamil Nadu): Government of Tamil Nadu (2019), p. 87. Since 2019-20, money received from the central government under PMMVY partly funds first-birth maternity benefits in Tamil Nadu.

KCR Ammavodi (Telangana): Coverage figures are not available.

As mentioned in the text, a few states have schemes that supplement PMMVY benefits. One example is Kasturba Poshan Sahay Yojana in Gujarat. Expenditure data suggests that coverage was very low in 2018-19.

\section{Other Acts and Schemes}

Other acts and schemes have a very limited coverage in terms of actual beneficiaries. They are of little consequence for the purpose of assessing the overall coverage of maternity benefits in India as things stand. Nevertheless, we tried to get an idea of their coverage. 
Employee State Insurance Act: As per data from the Employees' State Insurance Corporation, 42,722 cases of maternity benefits were paid in 2018-19. The annual average for the period 2011-12 to 2018-19 was 29,696 .

Maternity Benefit Act, 1961: According to back-of-the-envelope calculations by Rajagopalan and Tabarrok (2019, p. 175), "perhaps 2 percent of the labor force are potential beneficiaries of the law". However, the number of actual beneficiaries is likely to be much lower.

Scattered provisions for maternity benefits are also included in other acts such as the Unorganised Workers' Social Security Act 2008 and the Building and Other Construction Workers' Welfare Cess Act 1996, now repealed and superseded (with similar provisions) under the Code on Social Security. These provisions, however, have remained largely symbolic so far. 